\title{
NP-ellipsis with adjectival remnants: a micro-comparative perspective
}

\author{
Norbert Corver • Marjo van Koppen
}

Received: 20 January 2009 / Accepted: 15 October 2009 / Published online: 15 June 2011

(C) The Author(s) 2011. This article is published with open access at Springerlink.com

\begin{abstract}
Two strategies of NP-ellipsis have been identified in the literature: (a) the elision strategy, and (b) the pronominalization strategy. The former has been said to be dependent on the presence of inflectional morphology (i.e., agreement) on the adjectival remnant. The latter strategy is used when the adjectival remnant does not carry any inflectional morphology. The aim of this article is to show that there are languages, among which Dutch, where morphological agreement appears to be the licensing factor, but where one-insertion (i.e., the pronominalization strategy) is the actual strategy. We arrive at this conclusion via an in-depth and systematic micro-comparative investigation of NPE in a number of closely related languages and dialects, more specifically: Afrikaans, Frisian, (standard) Dutch and dialectal variants of Dutch. English will be included in our analysis as well, since it is a core example of the pronominalization (i.e., one insertion) strategy. At a more theoretical level, it will be shown on the basis of close inspection of our micro-variation data that the
\end{abstract}

The research reported on in this article is part of a larger research project entitled Diversity in Dutch DP Design (DiDDD), which is financially supported by The Netherlands Organization for Scientific Research (NWO). We are also grateful to the consultants of the DiDDD-project for providing us with the relevant data of their Dutch dialect. We would further like to thank our consultants for Afrikaans and Frisian for their help with and discussion of the data from their languages. For Afrikaans: Theresa Biberauer, Frenette Southwood and Johan Oosthuizen. For Frisian: Siebren Dyk, Eric Hoekstra, Jarich Hoekstra, Bouke Slofstra, Janneke Spoelstra, Willem Visser. We are also grateful to the three NLLT reviewers for their very useful comments. The content of this article was presented at a 2008 UCLA-minicourse entitled 'The study of syntactic microvariation: perspectives and tools', which was sponsored by a joint collaborative grant from the Universities of California and the University of Utrecht. We would like to thank the audience, and especially Hilda Koopman and Ed Stabler, for very useful discussion.

N. Corver · M. van Koppen ( $₫)$

Utrecht Institute of Linguistics-OTS, Utrecht University, Trans 10, 3512 JK, Utrecht,

The Netherlands

e-mail: J.M.vanKoppen@uu.nl

N. Corver

e-mail: N.F.M.Corver@uu.nl 
pro-nouns involved in the pronominalization strategy have a composite structure. It will be shown that this decompositional analysis of pro-nouns brings together (i.e., unifies) the elision strategy and the pronominalization strategy. Another outcome of our study will be that languages/dialects may have available more than one NPE strategy.

Keywords NP-ellipsis · Elision · Pronominalization · Pro-nouns · Adjectival agreement $\cdot$ Micro-variation

\section{Two types of ellipsis strategies}

The phenomenon of ellipsis in the nominal domain (henceforth referred to as Noun Phrase Ellipsis or NPE) has received a fair amount of attention in generative syntactic research of the last few decades. Taking a descriptive perspective and broadly defining NPE as covering both null (i.e., unpronounced) pronouns and lexical (i.e., pronounced) ones, we can identify two NP-ellipsis strategies across human languages: (a) the pronominalization strategy and (b) the elision strategy (cf. Ross 1967; Jackendoff 1977). ${ }^{1}$ According to the former, ellipsis involves replacement of some part of the noun phrase by a lexical (i.e., phonologically overt) pro-form. The latter strategy involves elision of some part of the noun phrase, yielding a noun phrase which is partially phonologically empty. The two strategies are illustrated in (1) and (2), where the English example (1a) represents the pronominalization strategy and the French example (1b) the elision strategy.

a. John bought a big car and Mary bought a small *(one).

b. J'ai acheté une voiture blanche et Marie a acheté une

I.have bought $\mathrm{a}_{\mathrm{fem} . \mathrm{sg} \text {. }}$ car white $_{\mathrm{fem} . \mathrm{sg} \text {. }}$ et Marie has bought $\mathrm{a}_{\mathrm{fem} . \mathrm{sg}}$. verte.

green $_{\text {fem.sg. }}$.

'I bought a white car and Marie bought a green one.'

Adopting here an adjunction analysis for attributive adjectives, we may depict the contrast between the two ellipsis strategies as in (2), where in the spirit of Kayne

\footnotetext{
${ }^{1}$ The characterizations 'pronominalization strategy' and 'elision strategy' are used here as descriptive labels. They reflect Ross's (1967) early discussion of the phenomenon of NP-ellipsis in English. According to him, NP-ellipsis, which strictly speaking involves the elision of part of the noun phrase, involves two derivational steps: (i) replacement of part of the noun phrase at deep structure by the pronoun one, as in (ia), and (ii) subsequent deletion of this pronoun by transformational rule, to derive the surface structure in (ib). Thus, Ross exploits this connection between ellipsis and pronominalization, proposing that the source of ellipsis in noun phrases is in fact the pronoun one. Jackendoff (1977) argues against this approach and proposes that ellipsis in noun phrases derives not from one-deletion, but rather from noun phrases that contain a base-generated, empty pronominal head (represented as PRO). In later work on NP-ellipsis written within the Government \& Binding-framework this empty pronominal is characterized as pro (i.e., a [+pronominal], [-anaphoric] empty category); see especially Lobeck (1991, 1995).
} 
(2003) the silent noun one represents the elided (i.e., unpronounced) nominal constituent: ${ }^{2,3}$

$$
\begin{aligned}
& \text { a. [DP a [NP small [NP one }]] \text { (pronominalization strategy) } \\
& \text { b. [DP une }[\mathrm{NP} \text { verte }[\mathrm{NP} O N E]]] \text { (elision strategy) } \\
& a_{\text {fem.sg. }} \text { green } n_{\text {fem.sg. one }}
\end{aligned}
$$

This contrast as regards the NPE-strategy has been associated with the presence versus absence of inflectional morphology on the adjectival remnant. More specifically, an adjective with morphological inflection (e.g., French verte 'green') is able to license a phonologically empty noun, whereas an adjective which lacks morphological inflection (e.g., English small) is unable to license it (see Lobeck 1991, 1995; Kester 1996).

Another language which seems to provide evidence for this correlation between morphological agreement on the adjective and the use of the elision strategy is Dutch. Consider the following examples (see also Muysken \& Van Riemsdijk 1986; Broekhuis et al. 2003):

$$
\begin{aligned}
& \text { a. Jan heeft [ een witte hond] gekocht en Marie heeft } \\
& \text { Jan has a white- } e \text { dog bought and Marie has }
\end{aligned}
$$

\footnotetext{
${ }^{2}$ In view of the ill-formedness of a small in (1a), one might jump to the conclusion that English does not have a silent counterpart of one. Kayne (2003), however, points out that even in English nominal constructions can be found in which a silent counterpart is arguably present. He gives the following minimal pair:
}

(i) big cars; big ones; *bigs

(ii) other cars; other ones; others

(i) shows that in the absence of a lexical noun, the pro-form one must be present. Interestingly, with the modifier other it turns out to be possible to leave out the overt pro-form one, as is illustrated in (ii). Rather than interpreting others as a complex word, Kayne hypothesizes that others actually has the representation in (iii). That is, there is a silent pro-form, represented as the silent noun one, which occupies the N-position.

(iii) other ONE s

According to this representation, the plural morpheme $-s$ is not attached to the adjective but rather to the silent noun, yielding the surface (i.e., pronounced) pattern others. Possibly, this analysis can be extended to forms such as smalls and biggers, which are sometimes found in colloquial (American) English (Ed Stabler p.c.). Consider the following examples (example (v) is drawn from Google).

(iv) The big ones (e.g., dresses) are here and the smalls are over there.

(v) As the olders (= older children) you were supposed to be the pillars of support for Mom and Dad.

As pointed out by a reviewer, an alternative approach to the form others would be to say that other is a category-neutral root which can surface as a noun or an adjective. In others it functions as a noun (as it arguably also does in the reciprocal each other) and, consequently, can bear plural morphology. Under this alternative analysis, the idea that English does not allow for the elision strategy might be maintained.

${ }^{3}$ In earlier generative analyses, the unpronounced noun of the elliptical noun phrase was represented as PRO (see Jackendoff 1977) or pro (see Lobeck 1991, 1995). Following Kayne (2003), we will represent the elided noun as one, since it nicely captures the fact that it is a pro-noun; i.e., it represents an empty Noun. In the article, we will sometimes use one in a language-neutral way; i.e., to indicate the ellipsis site in a language which does not have an overt pro-noun like English one. 
[een zwarte] gekocht.

a black- $e$ bought

'Jan bought a white dog and Marie bought a black one.'

b. Jan heeft [ een wit konijn] gekocht en Marie heeft

Jan has a white rabbit bought and Marie has

[een zwarte] gekocht.

a black-e bought

'Jan bought a white rabbit and Marie bought a black one.'

In (3a) the attributive witte 'white', which modifies the non-neuter noun hond 'dog', carries the adjectival inflection - $e$ (i.e., schwa). The adjective zwarte also carries this $-e$ and is consequently able to license a phonologically empty noun. Consider next (3b). Observe that the attributive adjective wit, which modifies the neuter noun konijn 'rabbit' does not carry the inflectional marker - $e$. Interestingly, for many speakers of Dutch, the marker - $e$ must appear when the neuter noun is elided; see the form $z$ wart-e. In short, NPE in Dutch seems to require the presence of inflectional morphology on the adjectival remnant, as depicted in (4):

$$
\begin{aligned}
& \text { [DP een [NP zwarte [NP ONE]]] } \\
& \text { a black- } e_{\text {non-neuter }} \text { one }
\end{aligned}
$$

(elision strategy)

Although the NP-ellipsis pattern een zwarte in (3b) strongly argues in favor of an elision analysis, as in (4), we will argue in this article that een zwarte actually is an instance of the pronominalization strategy. More specifically, the $-e$ (i.e., the sound schwa) which appears to be an adjectival inflection attached to lexical adjective zwart, turns out to be a phonologically weak NP pro-form. This pro-form is homophonous with the adjectival inflection - $e$ (as in een witte hond) and is grammatically similar to the English pro-form one. This means that the structural representation of the NPEpattern een zwarte corresponds to (5) rather than (4):

$$
\begin{gathered}
\text { [DP een [NP Zwart [NP } e]]] \\
\text { a black } e
\end{gathered}
$$

(pronominalization strategy)

The major goal of this article is to show for a variety of closely related languages that what appear to be instances of elision in NPE are actually instances of pronominalization. Or to put it from a different perspective: many apparent instances of adjectival inflection turn out to be pro-nouns, i.e., pronominals of the categorical type N. We will be able to show this by taking a micro-comparative view on NPE. This microcomparative approach will consist of an in-depth and systematic investigation of the following languages and dialects: Afrikaans, Frisian, (standard) Dutch and dialectal variants of Dutch. As will become clear in the course of the article, a crucial empirical domain in our argumentation is patterns of NPE of which the adjectival remnant consists of more than one adjective.

Besides showing that certain apparent adjectival inflections are actually pro-nouns, we will also present a more refined analysis of pro-nouns, which actually integrates the elision strategy (non-pronunciation of linguistic material) and the pronominalization strategy (pronunciation of linguistic material). More specifically, in the spirit of Marantz (1997), we will argue that pro-nouns have a composite structure which 
consists of two parts: a category-defining functional head $\mathrm{n}^{\circ}$ and an (anaphoric) root. It is the $\mathrm{n}^{\circ}$-part which defines the nominal status of the anaphor (e.g., English one). In the spirit of Kayne (2005), we will assume that the (non)pronunciation of the root depends on its syntactic position. More specifically, when the root occupies the Specposition of $n$, where $n^{\circ}$ is taken to be a phase head, the root will be invisible for spell-out at PF, which means that the root anaphor remains silent (i.e., ONE). A consequence of this compositional analysis of pro-nouns will be that the representation in (5) will ultimately look like (6):

$$
\begin{aligned}
& \left.\left[\text { DPeen [nP Zwart }\left[\mathrm{nP}^{\mathrm{ONE}}\left[\mathrm{nn}^{\prime}[\mathrm{n} e] \mathrm{t}_{\mathrm{i}}\right]\right]\right]\right] \\
& \mathrm{a} \text { black one } e
\end{aligned}
$$

An important outcome of our analysis will be that the various pro-nominal manifestations can all be reduced to properties associated with the functional category $n$. This, obviously, is in line with Borer's (1984) statement that parameterization is associated with the system of functional categories (see also Chomsky 1995, 2001). Related to that, it will become clear that parameterization in the domain of NP-ellipsis is not simply a matter of choice between the elision strategy or the pronominalization strategy. Rather, the two strategies can co-exist within a single language, something which is dependent on the properties of $n$.

The paper is organized as follows: In Sect. 2, we start our investigation into NPE with a discussion of the nature and behavior of the English pro-form one, which has been identified as a clear instance of the pronominalization strategy. In Sect. 3, we examine NP-ellipsis patterns in Afrikaans. Although Afrikaans appears to make use of the elision strategy, involving morphological richness of the adjectival remnant, we will show that, on closer inspection, this language makes use of pronominalization (i.e., presence of a lexical pro-noun). In Sect. 4, a more refined analysis of pro-nouns will be presented, according to which pro-nouns have a composite structure consisting of a functional category ${ }^{\circ}$ and a root. It will be shown that three NPellipsis variants of Afrikaans are manifestations of one and the same pro-nominal base-structure. In Sect. 5, we will continue our discussion with Frisian NPE-patterns. It will be shown that Frisian uses both the elision strategy and the pronominalization strategy. Also in this case, the NPE-surface manifestations can be reduced to a single pro-nominal structure. Building on our analyses of Afrikaans NPE and Frisian NPE, we try to give insight, in Sect. 6, into the NP-ellipsis strategies in Dutch, by taking a micro-comparative (i.e., cross-dialectal) perspective on Dutch NP-ellipsis. It will become clear in that section that the $-e$ on zwarte in ( $3 b)$ is a pro-noun rather than an adjectival inflection. This analysis will be more refined by saying that $-e$ is actually an instance of the functional category $\mathrm{n}$. Section 6 , finally, presents some conclusions.

\section{The English NP pro-form one}

Following Postal (1969), we argue in this section that English one in (1a) is a true pro-noun and as such should be analyzed as a pro-NP, as in (2a); see also Emonds (1985:162); Schütze (2001); Déchaine and Wiltschko (2002). The nominal (i.e., N) status of one is suggested by a number of morphosyntactic properties which they 
share with lexical nouns (see also Perlmutter 1970; Baker 1978; Wiltschko 1998; Schütze 2001; Panagiotidis 2003a, 2003b). First of all, it can inflect for number, as shown in (7). Secondly, it can be part of a DP headed by a determiner, as in (8). Thirdly, it can be preceded by a (sequence of) attributive adjective(s), as is illustrated in (9). And, finally, it can be followed by prepositional and clausal modifiers; see $(10 b)$ and $(11 b)$, respectively.

(7) a. The new designs are much better than the old designs.

b. The new designs are much better than the old ones.

(8) a. Do you like this picture better than that picture?

b. Do you like this one better than that one?

(9) a. Would you like the small red bike or the small blue bike?

b. Would you like the small red one or the small blue one?

(10) a. Peter recognized the man from Brazil and Bill the man from Cuba.

b. Peter recognized the man from Brazil and Bill the one from Cuba.

(11) a. For this desert I need bananas that are not fully ripe yet.

b. For this desert I need ones that are not fully ripe yet.

In view of this nominal behavior of the pro-form one, the conclusion must be that it is a category of the type $[+\mathrm{N},-\mathrm{V}]$; i.e., a noun. A further important characteristic is that it can only substitute for count nouns, and not for mass nouns (cf. Schütze 2001; Barbiers 2005):

a. Would you like a red bike or a white one?

b. *Would you like red wine or white one?

The pro-nominal status of one is suggested by its lack of descriptive content; i.e., it does not intrinsically refer to some object or entity, but receives its contents from a nominal antecedent (e.g., car in (1a)) or from a situationally available referent (as in: Wow, that's a fast one! [while speaker is pointing at a car]). ${ }^{4}$

\footnotetext{
${ }^{4}$ There is another way in which one semantically differs from regular nouns, namely it cannot occur with arguments (Lakoff 1970, crediting Baker; see also Jackendoff 1977: 58; Schütze 2001:134; Panagiotidis 2003a, 2003b):
}

(i) a. *Jack met the king of England, and I met the one of France.

b. Jack met the king from England, and I met the one from France.

(ii) a. *the treatment of Bill and the one of Sue

b. the treatment by the psychologist and the one by the psychiatrist

(iii) a. *the rumor that Bill would be fired and the one that John would keep his job

b. the rumor that John heard yesterday and the one that Mary had heard the day before

Traditionally, the ill-formedness of the a-examples in (i-iii) is explained by stipulating that one substitutes for the constituent $\mathrm{N}^{\prime}$. Under the assumption that one is a pro-noun, i.e., $\mathrm{N}^{\circ}$, this analysis is no longer available. However, following Schütze (2001) and Panagiotidis (2003a, 2003b), we will assume that the English pro-noun one does not project a complement position in syntax, because it has no thematic grid of its own. Nor is it able to inherit 'argumental' properties from the antecedent noun. Since this property of one is not crucial to the general idea in this paper we will not discuss this property of pro-forms like one in any further detail. 
The above-mentioned characteristics of one brings us to the following lexical characterization of this lexical pro-form.

$$
\text { one }\{[+\mathrm{N},-\mathrm{V}] \text {, [Count: }+],[\text { Number: sg/pl] }\}
$$

Thus, one is a pro-noun with a nominal categorial feature specification and a syntactico-semantic (i.e., formal) feature that expresses countability. It can further be used as a singular noun (one) or as a plural noun (ones).

On the basis of the phonological behavior of one we may further characterize one as a weak pronoun in the sense of Holmberg (1991), Cardinaletti (1998), Cardinaletti and Starke (1999), Corver and Delfitto (1999). As pointed out by Schütze (2001:130, 176), a sentence like (14) is acceptable with focus on green and deaccenting of ones, but unacceptable with focus on ones.

(14) We certainly like (the) green ones best

Now that we have identified the (weak) pro-nominal status of English one, we can start our investigation of NP-ellipsis patterns that appear to be instances of elision (i.e., a phonologically empty pro-noun which is licensed by morphological agreement) but actually are instances of pronominalization (i.e., presence of an overt pronoun). We start our investigation with Afrikaans.

\section{NP-ellipsis in Afrikaans}

In this section we will present an in-depth discussion of the patterns of NP-ellipsis as attested in Afrikaans. The basic NPE-patterns of Afrikaans are exemplified in $(15 b, c)$ :

Jan het ['n wit konyn] gekoop...

Jan has a white rabbit bought

a. en Pieter het ['n swart/*swarte konyn] gekoop. and Pieter has a black/black-e rabbit bought

b. en Pieter het ['n swart/*swarte een] gekoop. and Pieter has a black/black-e one bought

c. en Pieter het ['n swart- $e /$ *swart $^{\text {s }}$ gekoop. and Pieter has a black-e/black bought 'Jan bought a white rabbit and Pieter bought a black rabbit/a black one.'

Example (15) suggests that Afrikaans permits both the pronominalization strategy (cf., (15b)) and the elision strategy, featuring an inflectional morphology on the modifying adjective (cf., (15c)). Schematically:
a. [DP 'n [NP swart [NP een]]]
(pronominalization strategy)
b. [DP 'n [NP swarte [NP EEN]]]
(elision strategy)

We will argue that ' $n$ swarte, in fact, has the representation in (17), with $e$ being a phonologically weak pro-noun. 
As will become clear in the course of this section, we will argue that, in order to be able to determine the true nature of the Afrikaans NPE-pattern in (16b), it is of great importance to include instances of NPE involving adjectival remnants consisting of more than one adjective. The relevance of these NPE-patterns with complex adjectival remnants will also be shown in later sections for the other languages/dialects that we discuss in this article. To our knowledge, such data have largely or entirely been ignored in the literature on NPE so far.

\subsection{Adjectival inflection}

Before entering into a discussion of the NPE-patterns, we should first make a few remarks about the inflectional behavior of attributive adjectives in Afrikaans. As opposed to other Germanic languages, the presence versus absence of inflection on attributive adjectives is not determined by grammatical features such as gender, number, or (in)definiteness. ${ }^{5}$ This is exemplified in (18), which shows that the form of the attributive AP remains constant no matter what its direct syntactic surrounding is:

$$
\begin{array}{lll}
\text { a. } & \begin{array}{l}
\text { 'n/die mooi } \\
\text { a/the handsome }
\end{array} & \begin{array}{l}
\text { man } \\
\operatorname{man}_{\mathrm{sg}}
\end{array} \\
\text { b. } & \begin{array}{l}
\text { 'n/die mooi } \\
\text { a/the pretty }
\end{array} & \begin{array}{l}
\text { vrou }^{2} \\
\text { woman }_{\mathrm{sg}}
\end{array} \\
\text { c. } & \begin{array}{l}
\text { (die) mooi } \\
\text { (those) handsome guys }
\end{array} & \text { manne } \\
\text { d. } & \text { (die) mooi } & \text { vroue } \\
& \text { (those) pretty } & \text { women }_{\mathrm{pl}}
\end{array}
$$

A major factor in the inflectional behavior of the attributive adjective in Afrikaans is the syllabic form of the adjective. More specifically, monosyllabic adjectives such as mooi 'pretty/handsome', wit 'white', duur 'expensive', lang 'long', swart 'black', et cetera, typically do not carry any inflection (i.e., $-e$ ) when they are used attributively. On the other hand, polysyllabic ones such as lewendig 'lively', lelik 'ugly' and onverwagt 'unexpected' do carry inflection, see Donaldson (1993):6,7

\footnotetext{
versus non-neuter. /x/, and /s/ can also take $-e$; e.g.,

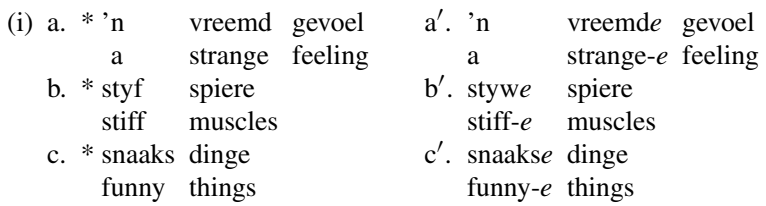

${ }^{5}$ As a matter of fact, Afrikaans does not morphologically distinguish the property 'gender'. For example, the form of the (in)definite article is constant and not sensitive to any gender distinction, such as neuter

${ }^{6}$ There are exceptions to this generalization; more specifically, monosyllabic adjectives ending in /d/, /f/, 

a. Jan het ['n wit konyn] gekoop.
Jan has a white rabbit bought
'Jan has bought a white rabbit.'
b. Jan het vandag [ 'n lang vergadering].
Jan has today a long meeting
'Jan has a long meeting today.'
c. Dit is ['n mooi kind].
this is a beautiful child
'This is a beautiful child.'
a. 'n lewendig*(e) wedstryd
a lively $(-e)$ match
b. 'n lelik*(e) gesig an $\operatorname{ugly}(-e)$ face
c. onverwagt* $(e)$ verliese
unexpected $(-e)$ losses

Thus, in noun phrases featuring a sequence of attributive adjectives, as in (21), it is possible to have one adjective carrying the inflection $-e$ and another one showing up in its bare form. Notice also that (21b) shows that the appearance of the $-e$ suffix is not subject to any linear adjacency requirement which states that $-e$ typically shows up when the attributive adjective is adjacent to the noun (though see fn. 8).
a. 'n lang lewendige vergadering
a long lively-e meeting
'a long, lively meeting'
an ugly-e green dress
'an ugly, green dress'
b. 'n lelike groen romp

\begin{abstract}
${ }^{7}$ The Afrikaans inflectional morpheme - $e$, which typically appears on polysyllabic adjectives, also behaves differently in other respects from the inflectional morpheme $-e$ that we find on attributive adjectives in a language like Dutch. The Afrikaans adjective lewendig, for example, (obligatorily) 'drops' its inflection (i.e., must be morphologically bare) when it is followed by the degree modifier genoeg (see (i)). As shown in (iib), it is impossible in Dutch to 'rescue' the structure by 'dropping' the adjectival inflection. This different behavior exemplified in (ib) and (iib) suggests that the Afrikaans adjectival inflection $-e$ and the Dutch one are different grammatical objects. For one thing, the Dutch adjectival inflection represents phi-feature properties, the Afrikaans inflection does not. As shown in (ic) and (iic), both languages block the appearance of $-e$ after genoeg, which suggests that this element cannot serve as a host to adjectival inflection (see Van Riemsdijk 1998).
\end{abstract}

(i) Afrikaans
a. 'n lewendige
a lively-e
wedstryd match
b. 'n lewendig(*e) genoeg
a lively $(e)$
c.* 'n lewendig
a lively

(ii) Dutch
a. 'n levendige wedstrijd
a lively-e match
b. *'n levendig $(e)$ genoeg wedstrijd
a lively $(e)$ enough match
c. *'n levendig genoege wedstrijd
a lively enough-e match 
Turning now to NP-ellipsis in Afrikaans, we observe the following two patterns: one pattern in which the noun is substituted for by a pro-form een, and a second pattern in which the adjective is followed by $-e$. The two patterns are illustrated in (22) for NP-ellipsis having a monosyllabic AP as a remnant:
Jan het [ 'n wit konyn] gekoop...
Jan has a white rabbit bought...
a. en Gert het ['n swart konyn] gekoop.
b. en Gert het ['n swart een] gekoop.
$(\mathrm{A}+e e n)$ and Gert has a black one bought
c. en Gert het ['n swart*(e)] gekoop.
$(\mathrm{A}+-e)$ and Gert has a black-e bought
d. *en Gert het ['n swarte een] gekoop. and Gert has a black-e one bought 'Jan has bought a white rabbit and Gert bought a black rabbit/a black one.'

Example (22b) exemplifies the een-strategy and (22c) the strategy featuring what, at first sight, looks like an inflection (i.e., $-e$ ) on the adjective. As shown in (22d), een and $-e$ cannot co-occur; they are in complementary distribution with each other.

Consider next NP-ellipsis having a polysyllabic AP as its remnant:
Jan het ['n pragtige konyn] gekoop...
Jan has a beautiful-e rabbit bought...
a. en Gert het ['n lelike konyn] gekoop. and Gert has a ugly-e rabbit bought
b. en Gert het ['n lelike een] gekoop. and Gert has a ugly- $e$ one bought
c. en Gert het ['n lelike] gekoop. and Gert has a ugly-e bought 'Jan has bought a beautiful rabbit and a Gert an ugly rabbit/an ugly one.'

Importantly, lelik, being a polysyllabic adjective, carries the adjectival inflection - $e$ when it is followed by an (overt) noun like konyn, as in (23a). This inflected adjectival form lelike is also attested before the pro-form een, as in (23b). Example (23c), finally, shows that lelike is also found when the noun is elided.

In what follows we will examine each of the two patterns more in depth, starting with the pattern featuring een, as in (22b) and (23b).

\section{2 'n swart een 'a black one': a pronominalization strategy}

We propose that een is the Afrikaans equivalent of English one. We further assume that, just like one, the pronoun een should be interpreted as a pro-noun; i.e., a pro- 
form that substitutes for the lexical part of the extended nominal projection, i.e., $\mathrm{N}(\mathrm{P}){ }^{8}$

The nominal (i.e., $[+\mathrm{N},-\mathrm{V}])$ status of een is supported by the fact that it can combine with the diminutive morpheme -etjie, which typically combines with nouns, as in mannetjie (mann + etjie, 'little man'), ringetjie (ring + etjie, 'little ring'): ${ }^{9}$

a. Pieter het [ die wit hasie ] gekoop en Gert het

Pieter has the white rabbit bought and Gert has

[die swart enetjie] gekoop.

the black one dim. $_{\text {bought }}$

'Pieter bought the white rabbit and Gert bought the (small) black one.'

b. een + etjie $_{\text {DIM }}$

According to Donaldson (1993:170), plural morphology is found after een in nonstandard speech, as in die groot enes (the big ones). Although our consultants reject this pattern, some of them do permit the presence of plural morphology when there is also diminutive morphology present after een, as in the following example: ${ }^{10}$
a. Pieter het [ die wit hasies] gekoop en Gert het
Pieter has the white rabbits bought and Gert has
[die swart enetjies] gekoop.
the black one dim.pl. bought
'Pieter bought the white rabbits and Gert bought the (small) black ones.'
b. een + etjie $_{\mathrm{DIM}}+s_{\mathrm{PL}}$

\footnotetext{
${ }^{8}$ As opposed to English one, Afrikaans een can combine with an internal argument, although some speakers feel a subtle contrast in well-formedness between (ia) and (ib).
}

(i) a. \% Ek vind [ die koningin van Nederland ] meer aangenaam

I find that queen of the.Netherlands more kind

as [die een van Engeland].

than the one of England

b. Ek vind [ die koningin uit Nederland ] meer aangenaam

I find that queen from the.Netherlands more kind

as [ die een uit Engeland].

than the one from England

(ii) [Die gerug dat Bill ontslaan sou word] en [die een dat Marie haar pos sou the rumor that Bill fired would be and the one that Marie her job would

behou], veroorsaak baie oproer.

keep caused much commotion

${ }^{9}$ The diminutive morpheme has other allomorphs besides -etjie: viz., -jie, -tjie, -kie, -pie, -ie. The ending depends on the final sound in the noun. The ending -etjie is found after monosyllabic nouns containing a short vowel and ending in $b, l, m, n, n g$ or $r$. See Donaldson (1993:87). As we will see later, we find the pronominal form ene besides een, especially in spoken language. Possibly, then, enetjie may (also) be formed from: ene + tjie.

${ }^{10}$ Thus, our consultants reject:

(i) * Pieter het die wit hasies gekoop en Gert het die swart enes gekoop. Pieter has the white rabbits bought and Gert has the black ones bought 
Finally, just like English one, Afrikaans een can only have a count reading, and not a mass reading:
a. Wil jy ['n rooi fiets] of ['n wit een] hê? would you a red bike or a white one have 'Would you like to have a red bike or a white one?'
b. * Wil jy [rooiwyn] of [witeen] hê? would you red.wine or white one have

In view of the above, we conclude that the Afrikaans grammatical noun een has the lexical properties in (27). Observe that it is slightly different from English one (see (13)) in the sense that it is lexically specified as being singular. ${ }^{11}$

$$
\text { een }\{[+\mathrm{N},-\mathrm{V}] \text {, [Count: }+] \text {, [Number: } \mathrm{sg}]\}
$$

\subsection{Een swarte (a black-e, 'a black one') as an instance of pronominalization}

Let us now turn to the second strategy used in Afrikaans NP-ellipsis, i.e., the pattern featuring - $e$ right after the attributive adjective swart in (15c). Obviously, the question should be addressed as to how to interpret this bound morpheme. As a first hypothesis, one might propose that $-e$ is an inflection, i.e., the same inflectional morpheme that is attached to polysyllabic adjectives like lelik in (20). Under such an analysis, - $e$ shows up after a monosyllabic adjective like swart as a sort of default inflectional suffix, which helps to license the empty noun position following the adjectival remnant. Although on the basis of 'simplex' noun phrases featuring an adjectival remnant consisting of a single adjective, this analysis might seem plausible, it is quite obvious that it should be rejected once we consider instances of NP-ellipsis in which the adjectival remnant of ellipsis consists of more than one adjective. Consider, for example, the following sentences:

Jan het [ 'n groot wit konyn] gekoop...

Jan has a big white rabbit bought...

'Jan bought a big white rabbit...'

a. en Piet het ['n groot swarte] gekoop. and Piet has a big black- $e$ bought 'and Piet bought a big black one.'

b. *en Piet het [ 'n grote swarte] gekoop. and Piet has a big- $e$ black- $e$ bought

c. *en Piet het ['n groot swart] gekoop. and Piet has a big black bought

d. *en Piet het ['n grote swart] gekoop. and Piet has a big-e black bought

\footnotetext{
${ }^{11}$ If Donaldson is correct about the possibility of having plural morphology after een, then arguably there are two variants of Afrikaans, one which permits een in the plural (i.e., the number-feature can be either singular or plural) and one which does not (as in (27)).
} 
The only well-formed pattern is (28a). In the elided noun phrase, it is only the final adjective (i.e., swart) in the sequence of (monosyllabic) adjectives that carries the morpheme $-e$. As shown by the ill-formed (28b), it is impossible to have - $e$ attached to both of the adjectives that together constitute the adjectival remnant. The pair (28a,b) suggests that $-e$ on swart should not be interpreted as an adjectival inflection, for, if it were an inflection, the marker $-e$ should arguably be present on both adjectives. The ill-formedness of (28c) is due to the absence of $-e$ on the adjectival remnant, more specifically, on swart. The ungrammatical (28d), finally, shows that the structure cannot be 'rescued' if the marker - $e$ is present on the first of the two adjectives.

Another observation that suggests that the marker $-e$ appearing after the adjective is not an inflectional marker comes from coordination. Consider the following example:
a. Dit is ['n dom en stout kind].
this is a stupid and naughty child
b. Dit is ['n dom en stout een].
this is a stupid and naughty one
c. Dit is ['n dom en stoute].
this is a stupid and naughty-e
'This is a stupid and naughty one.'

In $(29 \mathrm{a}-\mathrm{c})$, we find a noun phrase containing a coordinate structure consisting of two attributive APs. In (29a), the lexical noun kind 'child' is modified, in (29b) the grammatical noun een 'one' is modified. (29c) exemplifies the pattern featuring the marker $-e$. What is interesting is that in this example $-e$ only appears after the second adjective. That is, the monosyllabic adjective dom 'stupid' is not immediately followed by an instance of $-e$. The appearance of $-e$ only on the final (monosyllabic) adjective suggests that $-e$ is not an adjectival inflection, since adjectival inflections typically appear attached to each of the two coordinated adjectives. This is illustrated in $(30 a, b)$, where we have two coordinated polysyllabic adjectives.
a. Marie is ['n gelukkige en dankbare vrou].
Marie is a happy-e and grateful- $e$ woman
'Marie is a happy and grateful woman.'
b. *Marie is ['n gelukkig en dankbare vrou].
Marie is a happy and grateful-e woman

In (30), we see that both polysyllabic adjectives require the presence of the inflectional marker $-e$. When it is present only on the right adjectival conjunct, as in (30b), the structure is ungrammatical.

Now that we know that the $-e$ following the (monosyllabic) adjectival remnant in (29c) is not an adjectival inflection, the question should be raised as to what kind of element $-e$ is. Our first answer to this question is that $-e$ is a phonologically weak equivalent of the pro-noun een. That is, just like the pro-form een in (31a), the enclitic pro-form $e$ substitutes for $\mathrm{N}$, as in (31b): 
(31) Jan het [ 'n groot wit konyn] gekoop...

Jan has a big white rabbit bought...

'Jan bought a big white rabbit...'

a. en Piet het ['n [NP groot [NP swart [NP een]]]] gekoop.

and Piethas a big black one bought

b. en Piet het ['n [NP groot [NP swart [NP $e$ ] ]]] gekoop.

and Piet has a big black $-e$ bought

'and Piet bought a big black one.'

Some of the phenomena discussed above support the analysis in (31b). First of all, the complementary distribution of een and $-e$, as illustrated in (22d) follows if the $-e$ occupies the same syntactic position as the grammatical noun een. Secondly, the fact that $-e$ only appears right after the final adjective in a sequence of monosyllabic adjectives directly follows if $-e$ fills the N-position; see (28). From this perspective, ' $n$ groot swarte in (28a) has the same structural make-up as ' $n$ groot swart een in (31a), the only difference being the filler of the N-slot (see (31b)).

Thus, 'n grot-e swart-e in (28b) is out for the same reason why ' $n$ groot een swart een (a big one black one, 'a big black one') or for that matter 'n groot konyn swart konyn (a big rabbit black rabbit, 'a big black rabbit') is out. That is, neither the grammatical noun (een, $e$ ) nor the lexical noun (konyn) can combine with (i.e., select) a complement-noun phrase. As pointed out above, if - $e$ were simply some sort of adjectival inflection, it would remain unclear why only a single instance of A+-e can be part of the adjectival remnant of ellipsis.

Also the coordination pattern in (29c), with -e following only the second adjectival conjunct, is immediately accounted for if $-e$ is an element occupying the N-position. This is illustrated in (32b), which is structurally parallel to (32a), which features the strong pro-form een.
a. Dit is [' $\mathrm{n}$ [NP[AP dom en stout] [NP een]]]. this is a stupid and naughty one
b. Dit is ['n [NP[AP dom en stout] [NP $e]]]$. this is a stupid and naughty $-e$ 'This is a stupid and naughty one.'

Some additional support for the N-status of - $e$ comes from morphology. As the reader may recall, the grammatical noun een can be followed by a diminutive morpheme (cf. (24)). Since diminutive morphemes typically attach to nouns, we drew the conclusion that een is a noun-like element. What is interesting is that in Afrikaans we also find the diminutive morpheme attached after an $\mathrm{A}+-e$ combination like swart-e. This is exemplified in (33) and (34):
a. Jan het ['n wit hasie] gekoop en Gert ['n swartetjie].
Jan has a white rabbit bought and Gert a black- $e_{\text {dim }}$ 'Jan has a white rabbit and Gert has a black one.'
b. ['n [NP swart [NP $-e+t j i e]]]$ 
(34) a. Dit is 'n dom en stoutetjie.

this is a stupid and evil- $e_{\text {dim }}$

'This is a stupid and naughty one.'

b. ['n [NP [AP dom en stout] [NP -e+tjie]]

Another morphological argument in favor of the N-status of $-e$ comes from the distribution of the plural morpheme $-s$. As shown in (35), the plural morpheme $-s$ can be attached to the sequence A+-e (see also Kester 1996):

a. Jan het [ die groot wit hasies] gekoop en Gert het die

Jan has those big white rabbits bought and Gert has those

[groot swartes] gekoop.

big black-e-s bought

'Jan bought those big white rabbits and Gert bought those big black ones.'

b. Jan en Kees zijn [ dom en stoutes].

Jan and Kees are stupid and naughty-e-s

'Jan and Kees are stupid and naughty ones (e.g., boys).'

Consider, finally, the following example in which we find both a diminutive morpheme and a plural morpheme after the sequence $A+-e$ :

(36) Jan het [die soet wit hasies] gekoop en Gert

Jan has those sweet white rabbits bought and Gert

het [die soet swartetjies] gekoop.

has those sweet black $_{\text {dim.pl. bought }}$

'Jan bought those sweet white rabbits and Gert bought those (small) sweet black ones.'

The word swartetjies has the following structure: swart $+e+t j i e+s$, i.e., A-e-DIMPL. What looks like a single complex word at the surface, actually has a syntactic structure, namely:

$$
[\mathrm{NP} \text { swart }[\mathrm{NP}[\mathrm{N}-e+\mathrm{tjie}+\mathrm{s}]]]
$$

On the basis of the above-mentioned morphosyntactic properties, the following lexical characterization may be given of the pro-noun $e$ :

$$
e\{[+\mathrm{N},-\mathrm{V}],[\text { count:+], [number: } \mathrm{sg} / \mathrm{pl}]\}
$$

So far, we have argued that the $e$ which appears after a monosyllabic adjectival remnant in Afrikaans NPE is not an adjectival inflection, but rather a pro-form which 'substitutes' for N. ${ }^{12}$ Recall that polysyllabic adjectives do carry an adjectival inflection when they modify a noun; see (20). The question therefore arises how to

\footnotetext{
12 Also in Kester (1996:266 ff.), Afrikaans $-e$ in in swarte is not interpreted as an inflectional suffix. She argues that it occupies a functional head position $\mathrm{F}$ which takes pro as its complement.
} 
interpret $e$, when this element appears after a polysyllabic adjectival remnant in an NPE-environment. We will close off this section about Afrikaans NPE by addressing this question.

Consider the examples in (39):

Jan het ['n pragtige konyn] gekoop

Jan has a beautiful-e rabbit bought

a. en Gert het ['n lelike een] gekoop. and Gert has a ugly-e one bought

b. en Gert het ['n lelike] gekoop. and Gert has a ugly-e bought 'Jan bought a beautiful rabbit and Gert bought an ugly one.'

(39a) shows that the inflected adjective can be followed by an overt pro-form: een . Example (39b) suggests that lelike can also constitute an adjectival remnant on its own. A first hypothesis would be to say that, in (39b), there is a phonologically empty (i.e., silent) pro-form occupying the $\mathrm{N}(\mathrm{P})$-position, and that the morphology on the adjective ( $-e$ ) licenses the presence of the silent NP (see (40)). In other words, with an adjectival remnant consisting of a polysyllabic adjective (carrying agreement morphology), Afrikaans uses the elision strategy. Schematically:

$$
\text { ['n [NP lelike [NP ONE]]] }
$$

Such an analysis faces a number of problems, however. A first objection against this analysis is the following: Given the fact that the Afrikaans adjectival inflection - $e$ does not express any phi-features (gender, number), it is not really clear what the licensing role of $-e$ would be with respect to ONE. Furthermore, if $-e$ were an adjectival inflection licensing the presence of ONE, it would remain unclear why the pattern in (41c), where we have an adjectival remnant consisting of two coordinated polysyllabic adjectives, is out. That is, if a single inflected adjective is able to license ONE, why would not two coordinated inflected adjectives not be able to license the silent noun?
a. Marie is ['n gelukkige en dankbare vrou].
Marie is a happy-e and grateful-e woman
b. Marie is ['n gelukkige en dankbare een].
Marie is a happy-e and grateful- $e$ one
'Marie is a happy and grateful one.'
c. *Marie is ['n gelukkige en dankbare].
Marie is a happy-e and grateful-e

An alternative hypothesis about the NPE-pattern 'n lelike in (39b) would be to say that, similarly to monosyllabic adjectival remnants such as swart-e, polysyllabic adjectival remnants are actually followed by a phonologically weak pro-form $e$. Thus, the syntactic representation looks as in (42a), which is similar to the one corresponding to 'n lelike een in (42b): 

a. ['n [NP lelike $[\mathrm{NP}-e]]]$
b. ['n [NP lelike [NP een]]]

When the syntactic representation in (42a) is mapped onto phonology (i.e., receives a sound representation), only a single $e$-sound survives at the sound surface. That is, a sequence of identical sounds $e$ (in casu two schwas) is pronounced as a single schwa as a result of phonological deletion of one of the adjacent identical sounds. One might interpret this as a sort of haplology effect. ${ }^{13}$ We assume that the inflectional $-e$ is eliminated (under adjacency) and that the pro-form $e$ 'survives' at PF (i.e., lelik-e $e$ $=/$ le:likə/). ${ }^{14}$ The fact that the phonology of the pro-form wins from the phonology of inflection might be related to the fact that the pro-form $e$ is connected to meaning

\footnotetext{
${ }^{13}$ Normally, the notion of haplology is used for the elimination of a syllable when two consecutive identical or similar syllables occur. For the purposes of this article, we extend this notion here to the elimination of a sound in a sequence of identical sounds.

${ }^{14}$ A further illustration of the elimination of the sound 'schwa' when it is immediately followed by another sound 'schwa' comes from the Dutch examples in (i) and (iii), where we find instances of the adjectives stupide 'stupid' and morbide 'morbid', which used to be loanwords from French (17th century). Importantly, the $e$ that appears at the end of the adjective is not an adjectival inflection, which is shown by the fact that this $e$ also appears when the adjective modifies an (indefinite) neuter singular noun (see $\left(\mathrm{ia}^{\prime}, \mathrm{b}^{\prime}\right)$ ). Recall that the adjectival inflection $-e$ does not show up in these environments. Compare, for example, with: een stom(*-e) gezicht 'a stupid(*-e) look/face' and een stom(*-e) grapje 'a stupid(*-e) joke'.

(i) a. een stupide opmerking

a stupid remark $[+$ neuter, + sg]

b. een morbide grap

a morbid joke $[-$ neuter, + sg $]$

(ii) a. een nog stupider gezicht an even stupid-er look/face 'an even more stupid look/face'

$a^{\prime}$. een stupide gezicht

a stupid look/face $[+$ neuter, + sg]

$\mathrm{b}^{\prime}$. een morbide grapje

a morbid joke dim $[+$ neuter, + sg $]$

b. een nog morbider grapje

an even morbid-er joke

'an even more morbid joke'
}

The examples (ia,b), in which the attributive adjective modifies an indefinite non-neuter singular noun, display a single schwa-sound at the end of the word, even though adjectival modifiers typically take an adjectival inflection $-e$ in this structural context (Compare: een stomm*(-e) opmerking 'a stupid*(-e) remark' and een vreemd*(-e) grap 'a strange*(-e) joke'. That is, the surface forms stupide and morbide arguably look like (iiia,b) at a more abstract level but are pronounced with a single schwa-sound at the end of the word as a result of elimination of one of the schwas; let us assume the inflectional one), as is exemplified in (iiia' $\left.{ }^{\prime} \mathrm{b}^{\prime}\right)$.

(iii) a. een stupide- $e$ opmerking $\quad \mathrm{a}^{\prime}$. een stupide- $e$ opmerking

a stupid-e remark

b. een morbide- $e$ grap

a morbid-e joke

We propose that in (iia,b) a similar schwa-deletion process takes place. More specifically, the schwa of the comparative bound morpheme -er (as in: domm-er, stupid-er, 'more stupid' and vreemd-er, strange-er, 'more strange') is deleted when it is immediately preceded by the $e$ of stupide/morbide. Schematically:

(iv) a. een nog stupide-er gezicht $\quad a^{\prime}$. een nog stupide-er gezicht

an even stupid-compar look/face

'an even more stupid look/face'

b. een nog morbide-er grapje an even morbid-compar joke-dim 'an even more morbid joke'

$\mathrm{b}^{\prime}$. een nog morbide-er grapje

We would like to thank Mieke Trommelen for discussion of the contents of this note. 
(see (38)), whereas the inflection - $e$ is not; it is a meaningless sound, whose presence is solely triggered by the polysyllabic nature of the adjectival host. In other words, a meaningful sound wins from a meaningless one at the level of spell-out.

Support for the presence of a pro-form $e$ in Afrikaans NPE-contexts featuring a polysyllabic adjectival remnant comes from patterns such as those in (43b) and (44b), where a plural morpheme $-s$ and a diminutive morpheme -tjie, respectively, follow the adjectival remnant. ${ }^{15}$ The presence of these morphemes directly follows from an analysis which takes a phonologically weak pro-noun $e$ to occupy $\mathrm{N}$.

a. Ek werk liewer met [dankbare mense ] as met [ ondankbare

I work preferably with grateful people than with ungrateful mense].

people

b. \%Ek werk liewer met [dankbare mense] as met [ondankbares].

I work preferably with grateful people than with ungrateful- $e-s$

'I prefer to work with grateful people rather than with ungrateful ones.'

(44) a. Marie is ['n (on)dankbare enetjie].

Marie is an (un)grateful one dim

'Marie is an ungrateful one (e.g., child).'

b. \%Marie is ['n (on)dankbar-e-tjie].

Marie is an (un)grateful- $e_{\text {dim }}$

'Marie is an ungrateful one (e.g. , child).'

The question arises whether the analysis of ellipsis with polysyllabic adjectives exemplified in (42a) can shed some light on the quite surprising fact in (41c), i.e., the fact that two coordinated polysyllabic adjectives cannot occur as an adjectival remnant. Quite tentatively, we suggest that the ill-formedness results from a conflict between two requirements, namely, first of all, the requirement that haplology (i.e., deletion of a sound in a sequence of identical sounds) only applies when two sounds are linearly adjacent, and secondly the requirement that computational operations applying

\footnotetext{
${ }^{15}$ The symbol \% indicates that there is variation in the judgment of the linguistic expression by mother tongue speakers. This variation among speakers might be related to the haplology effect: i.e., suppose that for some speakers the haplology-rule cannot apply in the contexts at hand, i.e., the adjectival inflection marked in (i-ii) as - $e$ cannot be deleted even though it appears to be adjacent to the pro-noun $e$ at the sound surface. As we will argue in Sect. 4, there is an inaudible element (viz., the silent noun ${ }_{E E N}$ 'one', which occupies [SpecnP]) that intervenes between the polysyllabic adjective and the pro-noun $e$ (which will be reinterpreted as an istance of $\mathrm{n}$ ). Possibly, somewhat analogously to restrictions on wanna-contraction, this intervening one blocks the haplology-effect (i.e., reduction of a sequence of schwas to a single schwa) for certain speakers, resulting into the pronunciation of a sequence of schwas at the sound surface. Arguably, it is the hard/difficult pronunciation of this sequence of schwas which causes the pattern in (43b) and (44b). For those speakers who accept the forms in (43b) and (44b), the haplology effect arguably is not blocked.
}

(i) [NP ondankbare [NP $\left.\left.\mathrm{e}+\mathrm{s}_{\mathrm{pl}}\right]\right]$

(ii) [NP ondankbare [NP e+tje ]] 
to a coordinate structure typically operate in an across-the-board fashion. ${ }^{16}$ Let us clarify this by considering the representation in (45), where in line with the second hypothesis a weak pro-noun $e$ occupies $\mathrm{N}$ :

$$
\text { [DP 'n [NP [ConjP gelukkig-e [Conj' en dankbar-e]] [NP } e]]]
$$

In this representation, the two coordinated adjectives carry the inflection -e. Applying the haplology rule to the adjective dankbare 'grateful' would satisfy the adjacency requirement but be in conflict with the ATB-requirement on computational (including phonological) operations on coordinate structures. ${ }^{17}$ Notice that, if the deletion did apply in an ATB-way, yielding the ill-formed sequence *'n gelukkig en dankbare, we would have a violation of the adjacency requirement on haplology; the -e of gelukkige is not adjacent to the pro-form $e$. The two scenarios are depicted in (46): ${ }^{18}$

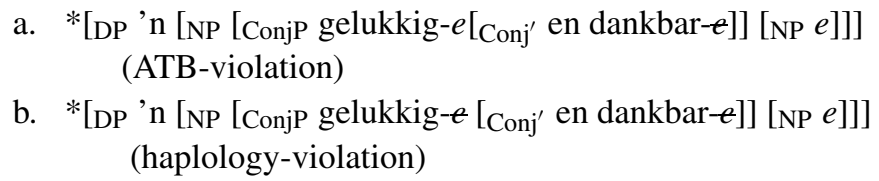

\footnotetext{
${ }^{16}$ Thus, a consequence of this analysis is that ATB rule application does not only hold of syntactic rules operating on coordinate structures but also to phonological rules. It goes without saying that deeper investigation of this proposal is necessary.

${ }^{17}$ Thus, haplology is a phonological rule which is active in the mapping of the syntactic structure onto a sound representation.

${ }^{18}$ It should be noted that it is also impossible to have an NPE-pattern featuring an adjectival remnant consisting of two coordinated adjectives, one of which is a monosyllabic (whence, uninflected) adjective and the other a polysyllabic (whence, inflected) one. This is exemplified in (ic). As shown by (ia,b), the coordinate structure is possible when there is present a lexical noun (vrou) or a strong pronominal form een.
}

(i) a. Marie is ['n mooi en dankbare vrou].

Marie is a pretty and grateful- $e$ woman

b. Marie is ['n mooi en dankbare een].

Marie is a pretty and grateful-e one

c. *Marie is ['n mooi en dankbare].

Marie is a pretty and grateful-e

'Marie is a pretty and grateful one.'

The question arises what causes the ill-formedness of (ic). Under the assumption that mooi is a morphologically bare adjective, the haplology rule only needs to apply to the right conjunct, as in (ii).

(ii) *[DP 'n [NP [ConjP mooi [Conj' en dankbar-e $]]$ [NP $e]]]$

Even though the linear adjacency requirement is satisfied in this structure, the structure is still out. We very tentatively propose that this should be interpreted as a sort of Coordinate Structure Constraint effect (cf. Ross 1967). More specifically, a computational rule (in this case a phonological rule deleting the adjectival inflection $-e$ ) only applies to a single conjunct. This is forbidden, just like it is forbidden to apply syntactic displacement to a single conjunct. 


\subsection{Conclusion}

From our investigation of NP-ellipsis in Afrikaans, the following picture emerges. Afrikaans is a language which uses a pronominalization strategy for NPE. It has two pro-forms which can substitute for N: First of all, the (phonologically independent) pro-noun een, which can be modified by a monosyllabic adjective (22b) or a polysyllabic one (23b). Secondly, it has a 'phonologically weak' pro-noun $-e$. This enclitic noun is homophonous with the adjectival suffix $-e$, which is found attached to polysyllabic adjectives. This pro-form $e$ is present in both NPE-contexts featuring a monosyllabic adjectival remnant (e.g., $n$ swarte) and in NPE-contexts featuring a polysyllabic adjective (e.g., $n$ lelike). In the latter example, the adjectival inflection - $e$ does not surface phonologically as a result of 'haplology'. An important piece of data in our analysis of NPE in Afrikaans came from NPE-patterns featuring an adjectival remnant consisting of more than one adjective, as in ' $n$ groot swarte (a big black-e, 'a big black one'). The fact that $e$ only appears after the final adjective of the adjectival remnant was taken as evidence for the fact that $e$ is not an adjectival inflection. A second way we have introduced in this paper to determine whether a certain ending is an adjectival inflection involves coordination of adjectives. The fact that the Afrikaans - $e$ does not appear on both adjectives in 'n dom en stoute (a stupid and naughty-e, 'a stupid and naughty one'), also indicates that this $-e$ is not an adjectival inflection.

\section{On the internal syntax of pro-nouns}

In the previous section we showed that the Afrikaans NPE-pattern ' $n$ swarte should be interpreted as an instance of pronominalization rather than elision. That is, $e$ is a pro-noun and not an adjectival inflection. In this section, we will take a closer look at the nature of pro-nouns, taking Afrikaans again as our point of departure. We will argue that pro-nouns have a composite syntactic structure: they consist of a functional category $n$, which takes a root in its complement position. It will be shown that the various intra- and interlinguistic pro-nominal manifestations can be derived from this pro-nominal 'base' structure.

\section{$4.1 e=\mathrm{n}$}

So far we have argued that both een and $e$ are instances of $\mathrm{N}$ in Afrikaans; more specifically, they are pro-nouns, just like English one. One might raise the question as to why Afrikaans, as opposed to, for example, English has two pro-forms, viz., $e e n$ and $-e$ ? As a matter of fact, it turns out that the situation is even more abundant given the fact that Afrikaans also has the form ene, a form we ignored so far in order not to further complicate the presentation of the Afrikaans data. Thus, besides the NPE-patterns ' $n$ swart een and ' $n$ swart-e, we also have ' $n$ swart ene. The existence of these three pro-nominal manifestations obviously raises the question as to whether there is any relationship between them. Of course, one might hypothesize that they are simply three lexical items stored in the lexicon, each of them being able to lexicalize the $\mathrm{N}$-position. Alternatively, one might explore the idea that there is a single 
lexical pro-form in Afrikaans, which surfaces in different forms (i.e., allomorphs): $e n e$ would be the complete form and een and $e$ the reduced ones (i.e., eene and respectively). Rather than defining the relationship between the three pro-forms at the level of morphophonology, we propose a unified analysis of them which is more syntactic in nature. For this, we make use of Marantz's (1997) proposal that the categorical nature of a word (i.e., the Root) is a derived property. Just like the functional category $\mathrm{v}$ determines the verbal character of the root $\mathrm{R}$ that is its complement, we will assume that the functional category $\mathrm{n}^{\circ}$ determines the nominal character of its (category-neutral) Root-complement. Thus, noun phrases are of the form $\mathrm{n}^{\circ}$-RP and the functional category $\mathrm{n}^{\circ}$ 'nominalizes' the root. By moving the root (e.g., Afrikaans konyn 'rabbit') to n, we obtain a nominal syntactic object, as in (47):

$$
\begin{array}{ll}
\text { a. } & {[n P[\mathrm{n}(=\varnothing)] \sqrt{ } \text { konyn }]} \\
\text { b. } & {\left[n P\left[n[\sqrt{ } \text { konyn }]_{j} \mathrm{n}(=\varnothing)\right] \mathrm{t}_{\mathrm{j}}\right]}
\end{array}
$$

If nouns have the form $\mathrm{n}^{\circ}$-RP, then arguably pro-nouns have the same form; how else could they be pro-nouns? Taking the Afrikaans lexical item een to be a categoryneutral root, we propose that its (pro)noun status is obtained by head-moving and adjoining een to n, as in (48):

$$
\left[\mathrm{nP}\left[\mathrm{n}[\sqrt{ } / \mathrm{een}]_{\mathrm{j}} \mathrm{n}(=\varnothing)\right] \mathrm{t}_{\mathrm{j}}\right] \quad(=e e n)
$$

Consider next the form ene, where we find $e$ (i.e., schwa, phonologically), attached to $e e n$. We propose here that $e$ instantiates $\mathrm{n}$. In other words, $e$ is a lexicalization of n. The pro-form ene can now be derived by head-raising and adjoining the root een to n. Schematically:

$$
\left[\mathrm{nP}\left[\mathrm{n}[\sqrt{ } \text { een }]_{\mathrm{j}} \mathrm{n}^{\mathrm{o}}(=\mathrm{e})\right] \mathrm{t}_{\mathrm{j}}\right] \quad(=\text { ene })
$$

Now what about the minimal form $e$, as in ' $n$ swart $e$ ? One might hypothesize that $e$ constitutes a bare $\mathrm{n}(\mathrm{P})$, as in (50):

$$
[n(P) e]
$$

But under the assumption that a functional category must combine with another category in order to be legitimate-more specifically, a categorizing functional head like $\mathrm{n}^{\circ}$ or $\mathrm{v}$ cannot operate vacuously-we propose that Afrikaans $e$ combines with a root R. ${ }^{19}$ Rather than saying that this root starts out as a silent root een in the complement position of $n$, we propose, in the spirit of Kayne (2005), that non-pronunciation (i.e., occurrence as a silent noun) is restricted to certain structural positions, more specifically the Spec position of a phase-head. Kayne (2005:295) argues that this follows from the following two principles:

\footnotetext{
${ }^{19}$ Embick and Marantz (2008) state the following 'categorization assumption': "Roots cannot appear (cannot be pronounced or interpreted) without being categorized; Roots are categorized by merging syntactically with category-defining functional heads." We state that the reverse also holds: a category-defining functional head (e.g., n, v) cannot appear without its Root. More in general, it holds that functional categories (C, T, D, et cetera) are never 'intransitive'; i.e., they always take a constituent in their complement position.
} 
(51) a. At a given phase level, only the head and material in the c-command domain of the head can (and must) be spelled out.

b. At a given phase level, no material within [...] a lower phase can be spelled out.

The combination of these two principles of spell-out have the effect that phrases in the Spec of a phase-head are invisible for spell-out. That is, 'phonology' cannot see material occupying these syntactic positions, and as a consequence an item occupying this position remains unpronounced (i.e., silent). Following Kayne's proposal about the non-pronunciation of constituents, the Afrikaans pro-noun $e$ can be assigned the following representation:

$\left[\mathrm{nP}[\sqrt{ } \mathrm{EEN}]_{\mathrm{j}}\left[\mathrm{n}^{\prime}[\mathrm{n}(=\mathrm{e})] \mathrm{t}_{\mathrm{j}}\right]\right.$ (movement to SpecnP yielding the surface form e)

Thus, the root $\sqrt{ }$ een moves to the Spec position of the functional head $\mathrm{n}$, which we take to be a phase head (see Embick and Marantz 2008). Occupying the Spec position, the root does not surface phonologically. ${ }^{20}$

This analysis of the internal syntax of pro-nouns brings us to the following (final) analysis of the various NPE-patterns in Afrikaans, where (53) involves a monosyllabic adjective and (54) a polysyllabic one.
a. [DP 'n [nP swart $\left.\left.\left[{ }_{n P}\left[\mathrm{n}[\text { een }]_{\mathrm{j}} \mathrm{n}(=\varnothing)\right] \mathrm{t}_{\mathrm{j}}\right]\right]\right]$
('n swart een)
b. [DP 'n [nP swart $\left.\left.\left[{ }_{n P}\left[n[\text { een }]_{j} n(=e)\right] \mathrm{t}_{\mathrm{j}}\right]\right]\right]$
c. [DP 'n [nP swart $\left.\left.\left[{ }_{n P}[E E N]_{j}\left[n^{\prime}[n(=e)] t_{j}\right]\right]\right]\right]$
('n swart ene)
a. [DP 'n [nP lelike $\left.\left.\left[n P\left[n[e e n]_{j} n(=\varnothing)\right] t_{j}\right]\right]\right]$
('n swarte)
b. [DP ' $n$ [nP lelike $\left.\left.\left[{ }_{n P}\left[n[\text { een }]_{j} n(=e)\right] t_{j}\right]\right]\right]$
('n lelike een)
c. $\left[\mathrm{DP}{ }^{\prime} \mathrm{n}\left[\mathrm{nP}\right.\right.$ lelike $\left.\left.\left[\mathrm{nP}[\mathrm{EEN}]_{\mathrm{j}}\left[\mathrm{n}^{\prime}[\mathrm{n}(=\mathrm{e})] \mathrm{t}_{\mathrm{j}}\right]\right]\right]\right]$
('n lelike ene)
('n lelike)

Notice, finally, that patterns such as 'n swartetjie (33a), die groot swartes (35a) and die soet swartetjies (36) can be derived under a structural analysis in which, along the lines of Borer (2005), additional functional layers encoding countability (Borer's Div(ider)P) and number (NumP) are added on top of $\mathrm{nP}$. Under the assumption that the diminutive morpheme is a possible realization of Div-in view of the fact that the diminutive morpheme turns a mass noun into a count noun-the form swartetjie can be derived via head movement and adjunction of the $\mathrm{n}^{\circ}$-head $e$ to Div, as is depicted in (55a); see Borer (2005), Wiltschko (2005), De Belder (2008). The plural form swartes results from movement of $e$ to the Num-head $-s$ (possibly via intermediate adjunction to Div). This is exemplified in (55b). The complex form swartetjies, finally, is derived by head-movement of $e$ to Div and by subsequent head movement of the complex head $[e+D i v]$ to Num, as in $(55 \mathrm{c}) .^{21}$

a. [DP 'n [DivP swart [DivP $\left.\left.\left.\left[\mathrm{e}_{\mathrm{k}}+[\mathrm{Div}-\mathrm{tje}]\right]\left[\mathrm{nP}[\mathrm{EEN}]_{\mathrm{j}}\left[\mathrm{n}^{\prime} \mathrm{t}_{\mathrm{k}} \mathrm{t}_{\mathrm{j}}\right]\right]\right]\right]\right]$

\footnotetext{
${ }^{20}$ In what follows we will not always represent the root category as $\sqrt{ }$.

${ }^{21}$ We will assume that adjectival modifiers can be adjoined at various levels within the extended nominal projection.
} 
b. [DP die [NumP groot $\left[\mathrm{NumP}\right.$ swart $\left[\mathrm{NumP}\left[\mathrm{e}_{\mathrm{k}}+[\mathrm{Div}-\mathrm{s}]\right]\left[\mathrm{nP}[\mathrm{EEN}]_{\mathrm{j}}\left[\mathrm{n}^{\prime} \mathrm{t}_{\mathrm{k}}\right.\right.\right.$ $\mathrm{t}_{\mathrm{j}}$ ]]]]]]

c. $\left[\right.$ DP $\operatorname{die}\left[\right.$ NumP soet $\left[\right.$ NumP $\operatorname{swart~}\left[\left[e_{k}+[\text { Div }-t j e]\right]_{m}-s\right]\left[\right.$ DivP $t_{m}\left[{ }_{n P}[E E N]_{j}\right.$ $\left.\left.\left.\left.\left.\left[\mathrm{n}^{\prime} \mathrm{t}_{\mathrm{k}} \mathrm{t}_{\mathrm{j}}\right]\right]\right]\right]\right]\right]$

In what follows, we will abstract away from these additional functional layers on top of $\mathrm{nP}$ and restrict ourselves in the discussion to the functional layer $\mathrm{nP}$.

\subsection{Towards a unified analysis of pro-nouns}

In Sect. 4.1 we have given a unified (decompositional) account of the pro-nominal variants een, ene and $e$. They all derive from the same base structure. The microdiversity as regards the pronomimal forms results from the following microparameters: (a) the lexicalization of $n^{\circ}$ (i.e., zero-realization or phonological realization as $e$ ); (b) the nature of the movement operation applied to the root (i.e., head movement to $\mathrm{n}^{\circ}$ or 'phrasal' movement to SpecnP); (c) the spell-out of the pronominal structure at PF (i.e., pronunciation as een or non-pronunciation as EEN). Notice that, in line with current assumptions about linguistic variation (cf. Borer 1984; Chomsky 2001), the above-mentioned dimensions of variation all relate to the functional system, more specifically $\mathrm{n}(\mathrm{P})$.

Having given an analysis of the pro-nominal variants of Afrikaans, the question obviously arises whether this analysis can be extended to English one, which we analyzed in Sect. 2 as a pro-noun. Under the decompositional approach in Sect. 4.1, we propose that one starts out as a root and head-adjoins to the functional category n, which is phonologically empty (Compare with Afrikaans (53a)). Schematically:

$$
\text { [DP a } \left.\left[\mathrm{nP} \text { black }\left[\mathrm{nP}\left[\mathrm{n}[\text { one }]_{\mathrm{j}} \mathrm{n}(=\varnothing)\right] \mathrm{t}_{\mathrm{j}}\right]\right]\right]
$$

Notice also that the analysis given for the Afrikaans pattern ' $n$ swarte in (53c) gives us a way of making sense of the French NPE-pattern une verte in (1b), repeated here as (57), which we descriptively characterized as an instance of the elision strategy:

$$
\begin{aligned}
& \text { J'ai acheté une voiture blanche et Marie a acheté une } \\
& \text { I.have bought } a_{\text {fem.sg. car white }} \text { fem.sg. et Marie has bought } a_{\text {fem.sg. }} \\
& \text { verte } \\
& \text { green } \\
& \text { 'I bough.sg. }
\end{aligned}
$$

Along the lines of (53c), we propose the following derived structure for une verte:

$$
\text { [une } \left.\left[\mathrm{nP} \text { verte }\left[\mathrm{nP}[\mathrm{ONE}]_{\mathrm{j}}\left[\mathrm{n}^{\prime} \mathrm{n}(=\varnothing) \mathrm{t}_{\mathrm{j}}\right]\right]\right]\right]
$$

As depicted in (58), the root has been moved to the Spec position of the phase head $\mathrm{n}^{\circ}$ and consequently is invisible to Spell-out at PF (cf. Kayne 2005). In other words, the root remains silent, which is represented here as ONE.

Recall from our introduction that it is traditionally assumed that the agreement morphology on the attributive adjective (in casu feminine singular) licenses the presence of an elided noun (cf. Lobeck 1991, 1995; Kester 1996). In a way, the 'nominal agreement' features 'gender' and 'number' on verte makes it possible to 'recover' 
the presence of the nominal head in the elliptical noun phrase. Suppose now that as a requirement on NP-ellipsis (used here in theory-neutral terms), the categorical status of the ellipsis site must be identified as being nominal. In the case of the Afrikaans NPE-variants in (53) and (54), the nominal status of the ellipsis site is identified by the presence of an overt instance of $\mathrm{n}$, viz., $e$, or by adjoining the root $e e n$ to $\mathrm{n}^{\circ}$ (yielding een or ene). Thus, the functional head $n^{\circ}$ must have lexical contents, so to say. In a language like French, which lacks an overt instance of $n^{\circ}$ and displays movement of the root to SpecnP, the categorical status of the ellipsis cannot be identified through these mechanisms. However, there is another mechanism these languages use: the agreement features gender and number realized on the adjective make it possible to identify the categorical nature of the elided site, since gender and number are essentially nominal properties. ${ }^{22}$

\subsection{On the layered structure of pro-nouns}

In the previous subsection, we argued especially on the basis of Afrikaans that pronouns are not 'simplex' syntactic objects but rather have an internal structure. The idea that pronouns can be decomposed into structural layers was first proposed by Postal (1969), who concluded on the basis of the formal similarity between definite articles and personal pronouns (as in French la fille 'the girl' and la 'her') that personal pronouns are in fact definite articles whose nominal 'partner' is missing. Abney (1987) adopts Postal's idea and, using the DP-hypothesis, generates both definite articles and personal pronouns in the functional head D. For Abney, the difference between definite articles and personal pronouns regards the presence versus absence of the lexical projection NP. Personal pronouns are, so to say, intransitive D's; i.e., they do not select an NP. Corver and Delfitto (1999), however, reject this intransitive analysis and argue that personal pronouns are in fact transitive D's: they select an NP-complement which is phonologically empty (pro, according to their analysis); see also Uriagereka (1995). An important motivation for this analysis is the fact that other functional heads such as $\mathrm{C}$ and I are always transitive, i.e., complement-taking heads. Although an analysis of the exact nature of personal pronouns falls beyond the scope of this paper, we bring up this transitive (i.e., D-NP) analysis of personal pronouns because it shows that personal pronouns (i.e., pro-determiners) have been argued to possess a layered internal structure. In Sects. 4.1 and 4.2 we have shown that pro-nouns (in the sense of Déchaine and Wiltschko 2002) also have a more complex structure, more specifically $n^{\circ}-R P$, where $n^{\circ}$ is Marantz's categorical node and $\mathrm{RP}$ the root. A conceptually attractive feature of this approach is that personal pronouns (i.e., D-pronouns) and pro-nouns (i.e., n-pronouns) have a similar structural

\footnotetext{
${ }^{22}$ In a certain way, then, the inflectional ending plays the role of a pro-noun (see also Roeper 2007:138). This would also tie in with the taxonomy of pronouns as defended in Déchaine and Wiltschko (2002). They argue that pronouns can be of three types: pro-DP, pro-PhiP and pro-NP. An example of the last category is the pro-form one, an example of a pro-DP is the English pro-form you or French le 'him'. Suppose now that the adjectival agreement morpheme (e.g., French - $e$, i.e., fem.sg.) is a pro-form of the phi-type. In other words, adjectival agreement morphology acts as a pro-noun too. The (pro-)nominal status of agreement morphology is, of course, also familiar from the clausal system. AGR-affixes have sometimes been analyzed as theta-bearing arguments in null subject languages (see, for example, Alexiadou and Anagnostopoulou 1998).
} 
make-up in the sense that they both have a composite structure. They, obviously, crucially differ in the contents provided by their functional heads: definiteness by D and nouniness by $\mathrm{n}^{\circ}$.

\subsection{Conclusion}

We have argued in this section that pro-nouns have the composite structure in (59).

$$
\text { [DP D [nP AP [nP Spec [n' } \left.\left.\left.\left.\mathrm{n}^{\circ} \mathrm{RP}\right]\right]\right]\right]
$$

The formal manifestation of the pro-nominal structure is dependent on a number of factors: (a) the lexicalization of $\mathrm{n}^{\circ}$ (i.e., zero-realization or phonological realization as $e$ ); (b) the nature of the movement operation applied to the root (i.e., head movement or movement to SpecnP); (c) the spell-out of the pronominal structure at PF (i.e., pronunciation as een or non-pronunciation as EEN). Following Kayne (2005), we argued that the root remains a silent noun (i.e., EEN) when it occupies SpecnP. The NPE-pattern that we have so far characterized as the 'pronominalization strategy' makes the nominal nature of the 'ellipsis site' manifest by moving the root (e.g., Afrikaans een, English one) to ${ }^{\circ}$ or by lexicalizing the n-head (e.g., Afrikaans $e$ ). In the NPE-pattern that we labeled 'elision strategy' the nominal nature of the ellipsis site becomes manifest via the nominal agreement features on the adjectival remnant of ellipsis. ${ }^{23}$

In what follows we will consider some further NP-ellipsis manifestations of the pattern in (59) by examining NP-ellipsis in Frisian (Sect. 5) and (variants of) Dutch (Sect. 6). At the more descriptive level of our discussion, we will keep using the labels 'elision strategy' and 'pronominalization strategy'.

\section{Frisian}

In this section we will discuss the NPE-strategies of Frisian. The main patterns to be considered are given in (60):

(60) a. Jan hie in witte auto en Geart in swarte. Jan has a white- $e$ car and Geart a black- $e$

b. Jan hie in witte auto en Geart in swarten/*swarte ien. Jan has a white- $e$ car and Geart a black-en/black- $e$ one

c. Jan hie in witte auto en Geart in swarten. Jan has a white- $e$ car and Geart a black-en 'Jan has a white car and Geart a black one.'

\footnotetext{
${ }^{23}$ See also Baltin and van Craenenbroeck (2008) for a unified approach towards NP-ellipsis and pronominalization.
} 
In theory-neutral terms, the pattern in (60a) represents the elision strategy: the adjectival remnant carries the bound morpheme $-e$, which is identical in form to the - $e$ on witte and may consequently be interpreted as an adjectival inflection. Pattern (60b) displays a potential equivalent of English one, viz. ien, and may consequently be taken to be an instance of the pronominalization strategy. A remarkable property of this NPE-pattern is the form of the adjectival remnant, viz. swarten. As indicated, the bound morpheme $-e$ is not allowed here. The question, obviously, arises as to whether the -en that follows the adjective should be analyzed as an adjectival inflection (see e.g., Barbiers 2005) or whether it should be interpreted as a pro-noun. We will defend the latter view. We will further show that the pronominal analysis extends to the pattern in (60c). A major outcome of our discussion will be that, just as with the Afrikaans NPE-manifestations, the patterns in (60) are essentially surface manifestations of the same underlying structure, more specifically the one in (59), which we also showed to be the basis of the Afrikaans NPE-patterns.

\section{1 in swarten (ien) (a black-en one, 'a black one'): a pronominalization strategy}

We will start our investigation into Frisian NP-ellipsis with the NP-pattern (60c). We propose that the bound morpheme -en is not an adjectival inflection, but rather a pro-form substituting for $\mathrm{N}$. In other words, it has the same status as the bound morpheme $e$ in the Afrikaans NPE-pattern 'n swarte (see (22c)). In line with our decompositional analysis of pro-nominals, we will argue that Frisian en can more precisely be characterized as an instance of the functional category $n^{\circ}$.

Evidence for the pro-nominal status of en comes from NP-ellipsis featuring an adjectival remnant consisting of a sequence of adjectives. Consider the following facts:

a. Jan hie [ in grut wyt skrift ] kocht

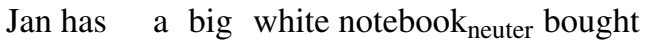

en Geart hie [in (*grutten) swarten ] kocht.

and Geart has a big-en black-en bought

'Jan bought a big white notebook and Geart bought a big black one.'

b. Jan hie [ in grutte wite auto] kocht

Jan has a big-e white- $e$ car common bought

en Geart hie [in (*grutten) swarten] kocht.

and Geart has a big-en black-en bought

'Jan bought a big white car and Geart bought a big black one.'

What these examples show is that it is impossible to have more than one A+-en combination within the adjectival remnant of ellipsis. Recall that in Afrikaans it was impossible to have more than one A+-e combination in the remnant of ellipsis, as in 'n groot/*grote swarte (a big(*-e) black-e, 'a big black one'). In Sect. 3, the impossibility of the sequence A+-e A+-e in Afrikaans was accounted for by saying that - $e$ actually is a weak pro-noun. Thus, Afrikaans ' $n$ grot-e swart-e is out for the same reason why 'n groot een swart een (a big one black one, 'a big black one') is out. That is, the pro-noun (een, $e$ ) cannot combine with (i.e., select) a complement-noun 
phrase. If Frisian -en in (61) were simply some sort of adjectival inflection, it would remain quite unclear why only a single instance of A+-en can be part of the adjectival remnant of ellipsis. From this, we conclude that en is an NP pro-form, analogously to Afrikaanse $e$ in ' $n$ swarte and English one in a black one. This brings us to the following initial representation for the Frisian NPE-pattern in swarten, which will be refined below on the basis of the hypothesis that pro-nouns, just like pro-determiners, have a composite structure. ${ }^{24}$

$$
\text { [DP in [NP swart [NP en ]]] (pronominalization strategy) }
$$

Considering next the NPE-pattern (60b), we observe that it displays exactly the same behavior as in swarten: the adjectival remnant of NP-ellipsis cannot consist of the sequence A-en A-en:

\footnotetext{
${ }^{24}$ Just like Afrikaans een and as opposed to English one, Frisian en can combine with a complement-PP or complement-clause. Thus, unlike English one, $(\mathrm{A}+e n)$ does not display any argument-adjunct asymmetry (Jarich Hoekstra p.c.). We will assume here that $e n$ is able to inherit the argumental properties of the antecedent noun. For the sake of completeness, we have also indicated that the argument-adjunct asymmetry is absent when we have the NPE-pattern 'in A+-en ien'.
}

(i) A+en (ien) + complement

Jitse wiisde him op [in posityf besprek fan syn roman] en Jitske op in

Jitse pointed-out him to a positive review of his novel and Jitske to a

[negativen (ien) fan syn samle fersen].

negative-en (one) of his collected poems

'Jitse pointed out to him a positive review of his novel and Jitske pointed out a negative review of his collected poems.'

(ii) $\mathrm{A}+$ en (ien) + PP-complement

Jitse wiisde him [in posityf besprek yn 'e krante] en Jitske op

Jitse pointed-out him a positive review in the newspaper and Jitske to

[in negative (ien) yn Hjir].

a negative-en (one) in Hjir

'Jitse pointed out to him a positive review in the newspaper and a negative review in Hjir (a literary journal).'

(iii) $\mathrm{A}+$ en (ien) $+\mathrm{CP}$-complement

Jan krige [in mûnlinge meidieling dat syn omke siik wie] en [in skriftliken (ien) Jan got an oral announcement that his uncle ill was and a written-en (one) dat syn heit stoarnwie].

that his father died had

'Jan got an oral announcement that his uncle was ill and a written announcement that his father had died.'

(iv) $\mathrm{A}+$ en (ien) $+\mathrm{CP}$-adjunct (i.e., relative clause)

Jan krige [in mûnlinge meidieling dêr't er net oars fan waard] en Jan got an oral announcement which that he not different from became and [in skrftliken (ien) $d y^{\prime} t$ er him tige neinaam] a written-en one which that he him(self) against took-offence.

'Jan got an oral announcement which he did not care about and a written announcement which he took offence at.' 
a. Jan hie [ in grut wyt skrift ] kocht

Jan has a big white notebook bought

en Geart hie [ in (*grutten) swarten ien] kocht.

and Geart has a big-en black-en one bought

'Jan bought a big white notebook and Geart bought a big black one.'

b. Jan hie [ in grutte wite auto] kocht

Jan has a big-e white- $e$ car bought

en Geart hie [ in (*grutten) swarten ien] kocht.

and Geart has a big-en black-en one bought

'Jan bought a big white car and Geart bought a big black one.'

Again this suggests that $-e n$ is not an adjectival inflection. The logical step seems to be that en is a pro-noun, as in (62). But then the question, obviously, arises as to how to interpret the lexical item ien, which seems to be the equivalent of English one and Afrikaans een. It is here where our compositional analysis of pro-nouns provides a solution. Under the assumption that (59) is the format provided by UG for pronominals, we may assign the following structure to Frisian in swarten ien: ${ }^{25,26}$

$$
\text { [DP in } \left.\left[\mathrm{nP} \text { swart }\left[\mathrm{nP}\left[\mathrm{n}^{\mathrm{O}}(=\mathrm{en})\right] \text { ien }\right]\right]\right] \quad \text { (in swarten ien) }
$$

According to this analysis, the lexical item en instantiates the functional node $\mathrm{n}^{\circ}$ and the lexical item ien constitutes the root. Note that this Frisian pattern completes the set of surface manifestations of the 'pronominal schema' considered so far. More specifically, it is a surface manifestation of the 'base pattern'; i.e., the pattern in which no pronoun-internal displacements have taken place (e.g., head movement of the Root to $\mathrm{n}$, or phrasal movement of the root to SpecnP).

The NPE-pattern in swarten, which we assigned the 'intermediate' analysis in (62) can now be assigned the more refined analysis in (65), which is parallel to the structural analysis of Afrikaans ' $n$ swarte in $(53 \mathrm{c}):^{27}$

$$
\text { [DP in } \left.\left[\mathrm{nP} \text { swart }\left[\mathrm{nP}[\mathrm{IEN}]_{\mathrm{j}}\left[\mathrm{n}^{\prime}\left[\mathrm{n}^{\circ}(=\mathrm{en})\right] \mathrm{t}_{\mathrm{j}}\right]\right]\right]\right] \quad \text { (in swarten) }
$$

\footnotetext{
${ }^{25}$ The element en is obligatorily present: *in swart ien.

${ }^{26}$ From an example like (i), in which the pro-form ien co-occurs with the numeral ien, we can conclude that the former should not be interpreted as a numeral.

(i) Jan hat [ twa grouwe skriften] en [ien tinnen ien].

Jan has two thick-e notebooks and one thin-en one

'Jan has two thick notebooks and one thin one.'

${ }^{27}$ With the exception of one speaker, all our Frisian consultants accepted the pattern A+-en for nominal constructions in which ellipsis has been applied to a plural noun:
}

(i) a. Ik ha leaver in tin skrift as in tsjokken.

I have preferably a thin notebook $\mathrm{s}_{\mathrm{sg}}$ than a thick-en $n_{\mathrm{sg}}$

'I rather have a thin notebook than a thick one.'

b. Ik ha leaver dy tinne skriften as dy tsjokken.

I have preferably those thin- $e$ notebooks $\mathrm{pl}_{\mathrm{pl}}$ than those thick-en $n_{\mathrm{pl}}$

'I rather have those thin notebooks than those thick ones.' 
As shown in (65), the root has been moved to the Spec position of the phase head $\mathrm{n}^{\circ}$. Following Kayne (2005), we will assume that material in this position can (and therefore must) be unpronounced.

\section{2 in swarte (a black-e 'a black one'): an elision strategy}

In this section, we will examine the Frisian NPE-pattern exemplified in (60a). Before discussing this pattern, we will first say a few words about the morphosyntactic behavior of attributive adjectives in non-elided nominal contexts. Consider for this the examples in (66) and (67), which show, respectively, adjectival inflection within a definite noun phrase and adjectival inflection within an indefinite noun phrase.
a. dat lytse hûs
that small-e house
b. dy lytse man / ko
that small-e man / cow
(neuter gender)
(common gender)
c. dy lytse hûsen / manlju / kij (plural) those small-e houses / men / cows
a. in lyts hûs (neuter gender)
a small house
b. in lytse man/auto (common gender)
a small-e man / car
c. lytse hûsen / manlju / kij (plural) small-e houses / men / cows

The inflectional pattern that emerges from these examples is the following: the inflectional ending $-e$ appears on all attributive adjectives, except for the attributive adjective modifying an indefinite neuter singular noun. In that case, the attributive adjective does not carry any morphological ending (see (67a)). ${ }^{28}$

Turning to NP-ellipsis, consider first NPE in the definite nominal paradigm.
a. dat $t_{\text {neuter }}$ lytse
that small
'that small one (e.g., house)'
b. dy common lytse
that small-e
'that small one (e.g., man / cow)'
c. dy lytse
those small-e
'those small ones (e.g., houses / men / cows)'

\footnotetext{
We tentatively assume that en is unspecified for number; i.e., its lexical entry does not include a number feature at all. Being unspecified for number, the pro-form en is 'neutral' with respect to the number property of the noun that is 'replaced'; i.e., it can be either singular or plural.

${ }^{28}$ This inflectional paradigm is similar to the one found for standard Dutch.
} 
Comparison of the paradigm in (66) with the one in (68) shows that the morphological form of the adjectival remnant of ellipsis is identical to the formal appearance of the adjective that modifies an overt noun. It seems plausible then that the $-e$ on lytse in (68) is an adjectival suffix. Under the assumption that presence of inflectional morphology on the adjective licenses a phonologically empty noun, the Frisian NPE-pattern in (68a) may somewhat more theory-neutrally be represented as in (69), which instantiates the elision strategy. Under the more refined analysis of pro-nouns as proposed in Sect. 4, it receives the structural analysis in (70). Recall that the inflectional features on the adjectives enable the identification of the contents of the functional head $n^{\circ}$. More specifically, the categorical status of the functional head $n^{\circ}$ is recoverable from the agreement properties associated with the adjectival remnant.

$$
\text { [DP dat/dy [NP lytse [NP IEN]]] (elision strategy) }
$$

Turning now to NP-ellipsis in Frisian indefinite noun phrases, we see a more diversified picture. First of all, the strategy in which the adjectival remnant consists of $\mathrm{A}+-e$ is attested when the elided noun has common (i.e., non-neuter) gender (cf. (71)). As shown by (72a), use of the bare adjectival form yields more versatile judgments: some speakers reject it, others find it quite acceptable but indicate that they prefer the NP-ellipsis pattern featuring en, as in in grutten (ien). ${ }^{29}$ All speakers agree that the remnant $\mathrm{A}+-e$ is excluded when the elided noun is a neuter (singular) noun (cf. (72b)).

(71) Jan hie in witte auto en Geart in swarte. (common gender noun (in A+-e)) Jan has a white- $e$ car and Geart a black- $e$

'Jan has a white car and Geart a black one.'
a. */?Jan hie in lyts hûs en Geart in grut. (neuter noun (*/?in A)) Jan has a small house and Geart a big 'Jan has a small house and Geart a big one.'
b. * Jan hie in lyts hûs en Geart in grutte. (neuter noun (*in A+-e)) Jan has a small house and Geart a big-e 'Jan has a small house and Geart a big one.'

The contrast between the well-formed (71) and the ill-formed (72b) suggests that the $-e$ on the adjectival remnant is not simply a weak NP pro-form that fills the $\mathrm{N}$-position. If it were a pro-form, one would expect it to be able to substitute for both neuter and common nouns. This leads us to assume that the $-e$ in (71) is an inflectional suffix on the adjectival remnant, which brings us to the elision analysis

\footnotetext{
${ }^{29}$ Hoekema (1996:10) gives the following Frisian example, in which the adjectival remnant either has the form lytsen or the form lyts:
}

(i) Ik ha leaver in grut hûs as in lyts(en).

I have preferably a big house than a small(-en)

'I prefer to have a big house over a small one.' 
in (73a), which under our compositional analysis of pro-nouns has the more refined structure in $(73 b)$ :

$$
\begin{aligned}
& \text { a. [DP in [NP swarte }[\mathrm{NP} \text { IEN]]] (elision strategy) } \\
& \text { b. [DP in } \left.\left[\mathrm{nP} \text { swarte }\left[\mathrm{nP}[\mathrm{IEN}]_{\mathrm{j}}\left[\mathrm{n}^{\prime}\left[\mathrm{n}^{\circ}\right] \mathrm{t}_{\mathrm{j}}\right]\right]\right]\right]
\end{aligned}
$$

Support for the inflectional status of $-e$ and against a weak pro-form analysis also comes from NP-ellipsis patterns featuring an adjectival remnant consisting of more than one adjective, where each adjective carries the inflectional suffix $-e:^{30}$

$$
\begin{aligned}
& \text { Jan had [ in grutte wite auto] en Geart [ in lytse swarte]. } \\
& \text { Jan had a big-e white-e car and Geart a small-e black-e } \\
& (\mathrm{A}+-e \mathrm{~A}+-e)
\end{aligned}
$$

'Jan had a big white car and Geart a small black one.'

Notice the contrast with the patterns in (61) and (63). This contrast strongly suggests that Frisian $e n$, as opposed to the $-e$ attached to the attributive adjective, should not be treated as an adjectival inflection.

The inter-speaker variation regarding the acceptability of the pattern in grut in (72a) possibly relates to a subtle difference in the morphological make-up of the adjective grut. More specifically, for those speakers who strongly reject in grut, the adjective is morphologically bare; i.e., there is no inflectional suffix attached to it, which represents the features 'neuter, indefinite, singular' (see (75a)). In other words, in this variant of Frisian, only common gender is represented morphologically (see (75b)). Suppose now that in the grammar of those speakers who find in grut in (72) quite acceptable, there is a zero-suffix attached to the adjective which represents the neuter gender property, as in (76). It is the presence of the gender feature represented by the zero-suffix which permits the licensing of the elided noun. The 'question mark' status may then possibly result from a combination of two factors: (i) the absence of an overt morphological reflex of the neuter-specification, and (ii) the availability of an alternative NPE-strategy (viz., in grutten) in which there is an overt marker present after the 'bare' adjective. In other words, speakers prefer an NPE-pattern in which an overt 'marker of ellipsis' is present.

\footnotetext{
${ }^{30}$ In line with our earlier observation regarding the distribution of adjectival $-e$ (see (72b)), it is impossible to have an adjectival remnant consisting of two stacked adjectives $\mathrm{A}+-e \mathrm{~A}+-e$ when the elided noun is contained within an indefinite, singular neuter noun phrase.
}

(i) *Jan hie in grut wyt skrift en Geart in lytse swarte. Jan has a big white notebook and Geart a small-e black-e

'Jan has a big white notebook and Geart has a small black one.'

For some speakers it is quite possible in those cases to have two morphologically bare adjectives as remnant of ellipsis. Others reject this pattern; compare with (72a).

(ii) */? Jan hie in grut wyt skrift en Geart in lyts swart. Jan has a big white notebook and Geart a small black 'Jan has a big white notebook and Geart a small black one.' 
a. [DP in $\left[{ }_{n P}\right.$ grut $\left.\left.\left[{ }_{n P}[I E N]_{j}\left[n^{\prime}\left[n^{\circ}\right] \mathrm{t}_{\mathrm{j}}\right]\right]\right]\right] \quad(*$ in grut; see $(72 \mathrm{a}))$

b. [DP in $\left[\mathrm{nP}\right.$ swarte $\left.\left.\left[\mathrm{nP}[\mathrm{IEN}]_{\mathrm{j}}\left[\mathrm{n}^{\prime}\left[\mathrm{n}^{\circ}\right] \mathrm{t}_{\mathrm{j}}\right]\right]\right]\right]$ (in swarte; see (71))

(76) [DP in [nP grut- $\left.\varnothing_{[\text {neut.indef.sg. }]}\left[\mathrm{nP}[\mathrm{IEN}]_{\mathrm{j}}\left[\mathrm{n}^{\prime}\left[\mathrm{n}^{\mathrm{O}}\right] \mathrm{t}_{\mathrm{j}}\right]\right]\right]$ ( $^{\text {in }}$ grut; see (72a); $\emptyset=$ zero-suffix)

For the sake of completeness, there is one other remark we should make: as shown by the examples in (68), the elision strategy is permitted within definite noun phrases. As shown in (77), the pronominalization strategy is blocked in Frisian when the noun phrase is definite (see Barbiers 2005):

$$
\begin{aligned}
& * \mathrm{dy}_{\text {common lytsen (ien) }} \\
& \text { that small-en (one) } \\
& \text { 'that small one' }
\end{aligned}
$$

The question, of course, arises as to what underlies this restriction of the pronominalization strategy to indefinite contexts. Notice at this point that Frisian differs in this respect from English (that big one) and Afrikaans (die mooi een 'that beautiful one'). At the moment we have nothing interesting to say about this contrast between Frisian, on the one hand, and Afrikaans and English, on the other. We leave this dimension of cross-linguistic variation for future research.

\subsection{Complex adjectival remnants in $\operatorname{swarten}($ ien $)$}

We close off this subsection with some intriguing facts about the morphological form of the non-final adjective in complex adjectival remnants (i.e., A A en). As was exemplified in (61), it is impossible to have a stacked structure of the following type: $\mathrm{A}+$ en $\mathrm{A}+e n$. Consider now example (78a) and (78b):
a. *?(?) Jan hat [ in grut wyt skrift] kocht Jan has a big white notebook bought en Geart hat [ in grut swarten] kocht. and Geart has a big black-en bought
b. ?(?) Jan hat [ in grut wyt skrift] kocht Jan has a big white notebook bought en Geart hat [ in grutte swarten] kocht. and Geart has a big-e black-en bought

As shown in (78a), our consultants generally reject the pattern in which we have a bare (i.e., non-inflected) adjective preceding $\mathrm{A}+e n$ (i.e., $\mathrm{A}+\mathrm{A}+e n$ ), even though the nominal antecedent of the pro-form en is a neuter indefinite singular noun. Those speakers who find this pattern deviant but nevertheless quite acceptable (i.e., compared to (78a)) typically also accept a morphologically bare adjective as an adjectival remnant (see in grut in (72a)). Another quite surprising pattern which some speakers find slightly deviant but still acceptable is the one given in (78b), i.e., $\mathrm{A}+-e \mathrm{~A}+e n$. That is, the adjective preceding $\mathrm{A}+e n$ carries an adjectival inflection - $e$.

The question arises how to interpret the patterns A A-en in (78a) and the pattern A-e A-en in (78b). Before giving an answer to this question, let us first of all point out that the pro-form en can substitute for nouns of different gender types (see (61), where 
en substitutes for the neuter noun skrift 'notebook' and the common noun auto 'car'). From this we may conclude that en is lexically unspecified for gender (cf. Barbiers 2005). Suppose now that the property of being unspecified for gender can be encoded in two ways: (a) complete absence of the gender feature in the featural make-up of en or (b) presence of an unvalued gender feature; i.e., gender [ ] (cf. Rooryck 1994). In the latter case, the gender feature can be inherited from the antecedent noun. Frisian speakers who use this inheritance strategy (mildly) allow the pattern in (78a). The unspecified gender feature [ ] inherits the gender feature from the antecedent noun skrift, and consequently the adjectives forming the adjectival remnant take the 'bare' surface form: grut and swart (compare with: in grut wit skrift).

Consider next the pattern (78b), in which the adjectival inflection - $e$ appears on grut. Clearly, the appearance of this inflection is incompatible with the [indefinite, neuter, singular] feature specification of the antecedent noun skrift 'notebook'. We propose that those Frisian speakers who find the pattern in (78b) quite acceptable, have a featural make-up of $e n$ which does not contain any gender-feature (i.e., the gender property is completely absent in the lexical entry of en). Given this, we make the claim that the $-e$ that appears on grutte in (78b) is a default inflection, whose sole function is to morphologically mark the dependency between the gender-less pronoun en and the attributive adjective(s) that constitute(s) the remnant of ellipsis. If the default inflection - $e$ on grutte 'big' in (78b) marks the dependency with the pronoun $e n$, then arguably the adjective immediately preceding en also carries a default adjectival inflection $-e$ in order to morphologically mark the dependency. We will assume, however, that this inflection never appears at the sound surface as a result of 'haplology'. That is, the adjectival inflection - $e$ (schwa) and the $e$ (schwa) of $e n$ are linearly adjacent and consequently pronounced as a single schwa at PF (here represented as deletion of the adjectival inflection $-e$ ). Schematically:

$$
\text { [in [NP grutte [NP swart-e [NP en ]]]] (= in grutte swarten) }
$$

\subsection{Conclusion}

In summary, Frisian has three patterns of NP-ellipsis: a pattern in which the root is in situ and the category-defining functional category is instantiated by en, as in in swarten ien. In the second NPE-pattern, the root has moved to SpecnP, which results into non-pronunciation of the root (i.e., we have a silent noun, as in in swarten). From a more descriptive point of view, these two patterns fall under the pronominalization strategy. Frisian also displays an NPE-pattern in which the n-head is not instantiated by en, as in in swarte, which represents the elision strategy. In this case, it is the agreement morphology on the adjective that makes the nominal nature of the ellipsis site recoverable. The form in swart, as found in NP-ellipsis constructions featuring elision of a $\mathrm{N}_{\text {neut.sg.indef }}$ is accepted by some speakers, but not all. ${ }^{31}$

\footnotetext{
${ }^{31}$ Recall from our discussion of Afrikaans that another potential test for identifying a bound morpheme as being pronominal rather inflectional comes from coordination. More specifically, an inflectional morpheme is expected to not be able to combine with two coordinated adjectives (i.e., *[A\&A]+infl); see Afrikaans (30b). A weak pronoun, on the contrary might be expected to take such a coordinate structure as its host
} 
Importantly, this form is not attested when the elided nominal head is part of a neuter indefinite singular noun phrase (see (72b)). Some speakers allow a bare adjective (cf. in grut in (72a)) in the latter structural context, but others reject that form. Frisian also exhibits the elision strategy, as in in swarte.

\section{NP-ellipsis in Dutch: a micro-comparative perspective}

In the introduction of this article, we made the statement that there are languages where morphological agreement (i.e., presence of agreement morphology) appears to be the licensing factor in NP-ellipsis, but where pronominalization (i.e., presence of an overt pronominal element) is the actual strategy. In Sects. 4 and 5, we pointed out that Afrikaans (e.g., 'n swart-e 'a black one') and Frisian (e.g., in swart-en (ien), 'a black one') fall within this class of languages. That is, $-e$ in the NPE-pattern in swarte and -en in the NPE-pattern in swarten (ien) are not inflectional morphemes attached to the adjectival remnant, but rather phonologically weak pro-nouns. More specifically, under our decompositional analysis of pro-nouns, we identified these elements as lexicalizations of the category defining functional head $\mathrm{n}^{\circ}$. Taking this

(i.e., [A\&A]+pro-noun); see Afrikaans (32b). Given the Afrikaans data, one might expect to find similar contrasts in Frisian. More specifically, if $e n$ is a pro-noun (i.e., n), one would expect it to be possible that it combines with a coordination of two adjectives; i.e., [A\&A]+en (ien). The structure [A\&A]-e, where the $-e$ is an adjectival inflection, is expected to be ill-formed. As shown by (i) and (ii), the latter is confirmed. Our Frisian consultants, however, also reject the pattern in (iiib), although some find (iiib) slightly less unacceptable than (iib).

(i) a. Jan hat [in lytse mar djoere auto]. (A-e \& A-e N)

Jan has a small-e but expensive- $e$ car

'Jan has a small but expensive car.'

b. *Jan hat [in lyts maar djoere auto]. (*A \& A-e N)

Jan has a small but expensive-e car

(ii) a. Jan hat $[$ in lytse mar djoere $]$ (A-e \& A-e)

Jan has a small-e but expensive- $e$

'Jan has a small but expensive one.'

b. *Jan hat [in lyts mar djoere].

Jan has a small but expensive-e

(iii) a. Jan hat [ in lytsen maar djoeren (ien)]. (A-en \& A-en (ien))

Jan has a small-en but expensive-en (one)

'Jan has a small but expensive one.'

b. *Jan hat [ in lyts mar djoeren (ien)]. (*A \& A-en (ien))

Jan has a small but expensive-en (one)

Although we leave an in-depth analysis of this contrast between Afrikaans and Frisian for future research, one might try to relate this contrast to the fact that in Afrikaans the monosyllabic adjective is truly bare whereas in Frisian it carries a default inflection $-e$ (see (79)). The ill-formedness of (iiib) might then be due to the fact that ATB-application of haplology violates the adjacency requirement (Compare Afrikaans (46b)). More specifically, the adjectival inflection $e$ on lyts in (iv) is not adjacent to the schwa that introduces en:

(iv) $*\left[\mathrm{DP}\right.$ in [NP [ConjP lyts- $e\left[\mathrm{Conj}^{\prime}\right.$ mar djoer-e $\left.]\right]$ [NP en (ien)]]] 
as our background, we will investigate in Sect. 6 the NPE-behavior of Dutch noun phrases. $^{32}$

Remember that an important piece of data was the example in $(3 \mathrm{~b})$, repeated here as (80).

Jan heeft [een wit konijn] gekocht en Marie heeft [een zwarte] gekocht. Jan has a white rabbit bought and Marie has a black-e bought 'Jan bought a white rabbit and Marie bought a black one.'

This example has always been taken as evidence for the idea that NPE in Dutch requires presence of overt adjectival inflection. Observe that, as opposed to the adjective wit in the noun phrase een wit konijn 'a white rabbit', the adjective zwart in the NPEpattern een zwarte 'a black one' must be followed by what appears to be an adjectival inflection. By taking a micro-comparative perspective on NP-ellipsis in Dutch, we will show that this $-e$ is not an adjectival inflection but should rather be analyzed as a phonologically weak pro-form, quite analogously to Afrikaans - $e$ and Frisian -en. Under our more refined, decompositional analysis of pro-nouns, this implies that the $e$ on zwarte in (80) is also an instance of the functional category $\mathrm{n}^{\circ}$.

\subsection{NPE in Standard Dutch}

Just as in Frisian (see (66-67)), adjectives agree for number, gender and definiteness in Standard Dutch. An overview of the inflection on attributive adjectives is provided in examples (81-82).

\begin{tabular}{|c|c|c|}
\hline a. & $\begin{array}{ll}\text { een witte } & \text { hond } \\
\text { a white-e } & \text { dog }\end{array}$ & (non-neuter singular indefinite) \\
\hline b. & $\begin{array}{l}\text { de witte hond } \\
\text { the white-e dog }\end{array}$ & (non-neuter singular definite) \\
\hline c. & $\begin{array}{l}\text { (de) witte honden } \\
\text { (the) white- } e \text { dogs }\end{array}$ & (non-neuter plural (in)definite) \\
\hline a. & $\begin{array}{l}\text { een wit } \\
\text { a white }\end{array}$ & (neuter singular indefinite) \\
\hline b. & $\begin{array}{ll}\text { het witte } & \text { konijn } \\
\text { the white-e } & \text { rabbit }\end{array}$ & (neuter singular definite) \\
\hline . & $\begin{array}{l}\text { (de) witte konijnen } \\
\text { (the) white-e rabbits }\end{array}$ & (neuter plural (in)definite) \\
\hline
\end{tabular}

As this overview shows, the attributive adjective in Dutch is always followed by a schwa (i.e., orthographically $-e$; phonetically $ə$ ), except when the noun phrase is indefinite, neuter and singular. ${ }^{33}$

\footnotetext{
${ }^{32}$ See Corver and van Koppen (2010) for a micro-comparative study of NPE-strategies involving a possessive pronoun as the remnant of ellipsis. In this article, it is pointed out that two strategies are used in Dutch dialects: (i) an elision strategy, involving agreement on the adjectival remnant, and (ii) a pro-form strategy, involving a weak pronominal form which fills the N-position.

${ }^{33}$ So Dutch is similar to Frisian in this respect; see (66)-(67).
} 
When we consider the ellipsis-counterparts of the noun phrases of (81-82) in (83), we observe that the form of the adjectival remnant is superficially the same as that of the attributive adjective in (81-82), more specifically: A+-e. There is, however, one exception to this formal identity: the adjectival remnant in the indefinite neuter singular noun phrase (e.g., een zwart konijn) changes from a bare form A (zwart) into $\mathrm{A}+-e$ (zwarte); see (83b). The use of the bare adjectival form zwart, as in een zwart, is considered to be deviant by certain speakers of Dutch, though not by all.

a. Jan heeft [een bruine hond] gekocht en Marie heeft

Jan has a brown-e $\operatorname{dog}_{\text {common }}$ bought and Marie has [een witte] gekocht.

a white-e bought

'Jan bought a brown dog and Marie bought a white one.'

b. Jan heeft [een wit konijn] gekocht en Marie heeft [een zwarte] Jan has a white rabbit neuter $_{\text {bought }}$ and Marie has a black-e gekocht.

bought

'Jan bought a white rabbit and Marie bought a black one.'

The question arises as to how to interpret the $-e$ on the adjectival remnant, especially in the case of een zwarte in (83b). As we have already mentioned before, it is generally assumed in the literature that $-e$ is an adjectival inflection (i.e., the same inflection that we find on the adjective in its attributive use) and that $-e$ is inserted as a default adjectival inflection when the elided noun is a $\mathrm{N}_{\text {neuter.sg.indef. (cf. Muysken and van }}$ Riemsdijk 1986; Kester 1996).

Corver and van Koppen (2009), however, present some data that suggest that this Dutch $-e$ is not an inflectional affix. They provide a case in which the attributive adjective cannot carry adjectival inflection and another one in which the addition of adjectival inflection results in a meaning difference. In those two cases, however, an - $e$ has to appear in ellipsis contexts, making the hypothesis that this $-e$ is an inflectional adjective quite unlikely.

First of all, they point out example (84-85), in which the attributive adjective can appear with or without the $e$-affix, depending on the meaning of the adjective.

Ik heb gisteren [ een groot/grote pianist] horen spelen.

I have yesterday a big/big-e pianist hear play

'I have heard a great/big pianist yesterday.'

Ik heb gisteren [ een echt grote] horen spelen.

I have yesterday a real big-e hear play

'I have heard a truly big/great one yesterday.'

The presence of the $e$-affix on the adjective groot 'big/great' affects its meaning: when it is present, the adjective means 'big', whereas it means 'great' when it is absent. In ellipsis contexts, however, the adjective has to carry an $e$-suffix independent of its meaning, as is shown in (85). This difference between the ellipsis and the non-ellipsis contexts casts doubt on the claim that the $e$-suffix is indeed an adjectival inflection in this case. 
A further illustration of the ambivalent character of the $e$-affix is provided in (86):
a. het doorbakken $(* e)$ konijn
b. het doorbakken* $(e)$
the well-baked(-e) rabbit
the well-baked(-e)
'the well-baked rabbit'
'the well-baked one'

As shown by (86a), adjectives that are derived from past participles ending in -en cannot show inflection. However, when used in ellipsis contexts, these participial adjectives must get the $e$-ending; see (86b). Again this suggests that the $e$-affix is not an adjectival inflection.

In view of these facts, we conclude that standard Dutch uses the pronominalization strategy for NP-ellipsis rather than the elision strategy. Thus, een zwarte in (83b), een echt grote in (85) and het doorbakkene in (86b) have the structures in (87a, b, c), respectively, where we abstract away from a decompositional analysis of pro-nouns.:
a. [DP een $[\mathrm{NP}$
zwart
[NP e ]]]
(pronominalization strategy)
b. [DP een $[\mathrm{NP}$
[echt groot] [NP e ]]]
c. [DP het $[\mathrm{NP}$
doorbakken [NP e ]]]

In what follows we will give a more precise characterization of the nature of NPellipsis in standard Dutch, and more specifically, of the nature of the marker $-e$. For this, we will examine NP-ellipsis in a number of Dutch dialects and look especially at the formal appearance of the adjectival remnant (see also Peters 1938). The data that will be presented are collected as part of the DIDDD-project (Diversity in Dutch DP Design), which is executed at the University of Utrecht (see Corver et al. 2007 for a discussion of the research methodology of this project). Besides this cross-dialectal investigation, we also make the pronominalization analysis in (87) more precise by analyzing the Dutch NPE-patterns in terms of the decompositional approach towards pro-nouns, as sketched in Sect. 4.

\subsection{Asten Dutch: $-e$ as an inflection}

We start our discussion with Asten Dutch, which is spoken in the province of Northern Brabant/The Netherlands. As shown by the indefinite paradigm in $(88 \mathrm{a}, \mathrm{b}, \mathrm{c})$ and the definite paradigm in (89a, b, c), this dialect morphologically distinguishes all three genders, i.e., masculine, feminine and neuter, on the attributive adjective. The masculine inflection corresponds to $-e n$, the feminine one to $-e$, and the neuter one lacks any overt morphology.
a. ne schonen opa a nice-en grandfather masc $_{\text {. }}$
b. een leuke oma a nice-e grandmother $r_{f e m}$
c. een leuk keind a nice child neut $_{\text {}}$
a. de schoonen opa the nice-en grandfather $r_{\text {masc }}$



b. de deftige oma
the poshy-e grandmother fem $_{\text {f }}$
c. het leuk kind
the nice child

Consider now the following examples of NPE with AP as the adjectival remnant:
a. [Talking about cars...]
Hij het pas ne nijen gekocht.
(masc.)
He has recently a new-en bought
'He has recently bought a new one.'
b. [Talking about cows...]
Hij het pas een bonte gekocht. (fem.)
He has recently a multi-colored-e bought
'He has recently bought a multi-colored one.'
c. [Talking about rabbits...]
Hij het pas een zwart gekocht. (neut.)
He has recently a black bought
'He has recently bought a black one.'

What we see is that the adjectival remnant of ellipsis has exactly the same form as in the non-elided noun phrases in (88). This strongly suggests that the markers -en and $-e$ are really inflections. In (90c), where the neuter noun is elided, the adjectival remnant keeps its bare form at the sound surface.

For this dialect we can apply the same test we have used to determine the status of -en and $-e$ in respectively Frisian in Sect. 5 and Afrikaans in Sect. 3: the behavior of this element in a sequence of adjectives. Notice that, if the adjectival remnant consists of a sequence of attributive adjectives, the form of each adjective remains the same. For example:

a. [Talking about cars...]

Ik wil zo'n grote gele, nie zo'n grote gruune.

(masc.)

I want such.a big-e yellow-e not such.a big-e green-e

'I want such a big yellow one, not such a big green one.'

b. [Talking about candies...]

Ik wil zo'n groot geel, nie zo'n klein geel.

I want such.a big yellow not such.a small yellow

'I want such a big yellow one, not such a small yellow one.'

In (91a), where the masculine noun auto 'car' is elided, we find two adjectival remnants, each consisting of a sequence of adjectives: grote gele 'big yellow one' and grote gruune 'big green one'. On each of the adjectives, we find the inflectional suffix $-e$. In (91b), ellipsis has applied to a neuter noun. Notice that the adjectival remnants (i.e., groot geel and klein geel) consist of superficially bare adjectives; that is, no overt morphological inflection is added to the adjectival remnant.

On the basis of the NPE-behavior displayed by Asten Dutch, we conclude that this dialect makes use of the elision strategy: the agreement properties on the adjectival 
remnant make it possible to license a silent noun. Thus, the NPE-representation may be represented as in (92):
a. [DP ne [NP nijen [NP ONE ]]]
b. [DP een [NP bonte [NP ONE ]]]
c. [DP een [NP Zwart- $\phi$ [NP ONE ]]]

Under the decompositional approach towards pro-nouns as sketched in Sect. 4, the patterns in (92) may be represented in a 'more refined' way as in (93). The root occupies the Spec-position of $n$, where it is invisible for Spell-out at PF. In other words, the root remains unpronounced, i.e., ONE.
a. [DP ne $\left[\mathrm{nP}\right.$ nijen $\left.\left.\left[\mathrm{nP}[\mathrm{ONE}]_{\mathrm{j}}\left[\mathrm{n}^{\prime} \mathrm{n}^{\circ}(=\varnothing) \mathrm{t}_{\mathrm{j}}\right]\right]\right]\right]$
b. [DP een $\left[{ }_{n P}\right.$ bonte $\left.\left.\left[{ }_{n P}[\mathrm{ONE}]_{\mathrm{j}}\left[\mathrm{n}^{\prime} \mathrm{n}^{\circ}(=\varnothing) \mathrm{t}_{\mathrm{j}}\right]\right]\right]\right]$
c. [DP een $\left[n P\right.$ Zwart- $\left.\left.\phi\left[n P[\mathrm{ONE}]_{\mathrm{j}}\left[\mathrm{n}^{\prime} \mathrm{n}^{\circ}(=\varnothing) \mathrm{t}_{\mathrm{j}}\right]\right]\right]\right]$

As indicated in (92c) and (93c), we will assume that the superficially morphologically bare adjective zwart in (90c) - and consequently also the adjectives groot, geel and klein in (91b) — carries a zero-suffix. This zero-suffix represents neuter gender and is able to license the silent pro-form; i.e., the nominal nature of the silence is, so to say, recoverable via the agreement features associated with the adjective, even when those features have no morphological overtness.

\subsection{Zierikzee Dutch: -en as an weak pro-noun}

A second type of dialect is Zierikzee Dutch, which is spoken in the province of Zeeland/The Netherlands. Similarly to standard Dutch, this dialect has a two-way gender system; that is, neuter versus common (i.e., non-neuter):

$$
\begin{aligned}
& \text { a. een leuke opa (common) } \\
& \text { a nice- } e \text { grandfather } \\
& \text { b. een leuke opoe (common) } \\
& \text { a nice- } e \text { grandmother } \\
& \text { c. een leuk kind (neuter) } \\
& \quad \text { a nice child }
\end{aligned}
$$

(95) a. de leuke opa (common) the nice- $e$ grandfather

b. de leuke opoe (common) the nice- $e$ grandmother

c. het leuke kind (neuter) the nice- $e$ child

This inflectional paradigm looks the same as the standard Dutch attributive adjectival paradigm. That is, we find the inflection $-e$ on all adjectives except for the attributive adjective in a neuter singular indefinite noun phrase (i.e., (94c)). 
When we consider next the adjectival paradigm in the NPE-contexts, we observe something interesting: the adjectival remnant is always accompanied by the marker $-e n .^{34}$

(96) a. [Talking about cars...]

Hie ei pas een nieuwen gekocht.

(common)

He has recently a new-en bought

'He has recently bought a new one.'

b. [Talking about cows...]

Hie ei pas een bonten gekocht. (common)

He has recently a multi-colored-en bought

'He has recently bought a multicolored one.'

c. [Talking about rabbits...]

Hie ei pas een zwarten gekocht. (neuter)

$\mathrm{He}$ has recently a black-en bought

'He has recently bought a black one.'

Notice further that if the adjectival remnant consists of a sequence of adjectives, it is only the last one which carries the marker -en. Thus, a sequence like zo'n groten gelen (such a big-en yellow-en) is ill-formed. The attributive adjective that precedes A+-en carries the inflection -e. This is exemplified in (97):

a. [Talking about cars...]

Ik wil zo'n grote gelen, nie zo'n grote grunen.

I want such.a big-e yellow-en, not such.a big-e green-en (common gender)

'I want such a big yellow one, not such a big green one.'

b. [Talking about sweet candies...]

Ik wil zo'n grote gelen, nie zo'n kleine gelen.

I want such.a big-e yellow-en, not such.a small-e yellow-en (neuter gender)

'I want such a big yellow one, not such a small yellow one.'

The NP-ellipsis strategy of Zierikzee Dutch is reminiscent of the one attested in Afrikaans and Frisian. Recall that in Afrikaans only the final adjective in a sequence of (monosyllabic) adjectives constituting the remnant of ellipsis carries the marker - $e$ (e.g., 'n groot swart-e, *'n grot-e swart-e, 'a big black one'). For Frisian, we saw that only the final adjective is able to carry the marker -en (*in grutten swarten, 'a big black one', ?/(?) in grutt-e swarten). In view of this similarity, we propose that Zierikzee Dutch uses the pronominalization strategy for noun phrase ellipsis: more specifically, en is a (weak) NP-pro-form, as in (98).

\footnotetext{
${ }^{34}$ This pattern of NPE is typically found in dialects spoken in the province of Zeeland/The Netherlands. Other dialects in the DiDDD-database which display this phenomenon are: Scherpenisse Dutch, Oostkapelle Dutch, and Axel Dutch.
} 
(98)

[ een [NP nieuw/bont/zwart [NP en]]]
a new/multi-colored/black en
'a new/multi-colored/black one'

Under a more refined analysis in which pro-nouns have a composite structure, the Zierikzee Dutch NPE-pattern can be represented as in (99), where en is the lexicalization of the functional category $n^{\circ}$ and one represents the root which remains unpronounced in the Spec position of $n^{\circ}$.

$$
\begin{aligned}
& {\left[\mathrm{DP} \text { een }\left[\mathrm{nP} \text { nieuw/bont/zwart }\left[\mathrm{nP}[\mathrm{ONE}]_{\mathrm{j}}\left[\mathrm{n}^{\prime} \mathrm{n}^{\circ}(=\text { en }) \mathrm{t}_{\mathrm{j}}\right]\right]\right]\right]} \\
& \text { a new/multi-colored/black } \\
& \text { 'a new/multi-colored/black one' }
\end{aligned}
$$

There is one additional remark, we should make here: As shown in (97), the non-final adjectives in the NPE-remnant also carry an inflection affix, namely - $e$ : grote 'big' and kleine 'small'. Especially, the example in (97b) is telling: the adjective carries an inflection $-e$, even though the discourse-anteceding noun (i.e., zuurke 'candy') has neuter gender. As shown in (94c), neuter (indefinite) nouns typically combine with a 'bare' (i.e., uninflected) adjective. So, why do we get the sequences grote gelen and kleine gelen rather than * groot gelen and *klein gelen in $(97 \mathrm{~b})$ ?

Recall that we had a similar situation in Frisian. Reconsider the examples in (78b), repeated here as (100).

(100) ?/(?) Jan hat [ in grut wyt skrift] kocht Jan has a big white notebook bought en Geart hat [ in grutte swarten] kocht. and Geart has a big-e black-en bought 'Jan has bought a big white notebook and Geart has bought a big black one.'

To account for these data we argued that the pro-noun -en for these speakers lacks a gender feature. As a consequence the adjective grut agreeing with this gender neutral element appears with the default inflection $-e$.

Our analysis of the data in (78b) is similar to the analysis we gave for the Frisian data in (100). The attributive adjectives grote 'big' and kleine 'small' modify an $\mathrm{NP} / \mathrm{nP}$ which is headed by the pro-form en. In view of the fact that $e n$ is able to substitute for both common (94a, b) and neuter (94c) nouns, we propose that en in Zierikzee Dutch, just like en in the Frisian example (100), is genderless (i.e., its lexical entry does not have a gender feature). We further propose that in those contexts, just like in Frisian, the inflected form $\mathrm{A}+-e$ is chosen as a default inflection. Schematically, with (101a) represents the pronominalization strategy and (101b) the more refined decompositional analysis of pro-nouns.

(101) a. [zo'n [AP grote [NP gele [NP en]]]]

(pronominalization strategy)

b. [zo'n [nP grote $\left[{ }_{n P}\right.$ gele $\left.\left.\left.\left[{ }_{n P}[\mathrm{ONE}]_{\mathrm{j}}\left[\mathrm{n}^{\prime} \mathrm{n}^{\circ}(=\mathrm{en}) \mathrm{t}_{\mathrm{j}}\right]\right]\right]\right]\right]$ 
As indicated, we will assume that the $e$ on gele is eliminated at PF as a result of haplology.

\subsection{Standard Dutch and other varieties}

In Sects. 6.2 and 6.3, we saw that two NP-ellipsis strategies are used in Dutch dialects: the elision strategy (Asten Dutch) and the pronominalization strategy (Zierikzee Dutch). The question arises as to what strategy is used in standard Dutch. Consider again the relevant example from standard Dutch, which has mostly been interpreted as evidence that Dutch requires the presence of adjectival inflection in the licensing of NP-ellipsis:

(102) Jan heeft [ een wit konijn] gekocht Jan has a white rabbit bought en Marie heeft [ een zwarte/\%zwart] gekocht. and Marie has a black-e/black bought 'Jan bought a white rabbit and Marie bought a black one.'

On the basis of the available strategies, two potential analyses come to mind for the NPE-pattern een zwarte in (102): (i) $-e$ is an inflection and the noun is elided (see (103a)); (ii) - $e$ is an enclitic pro-noun (cf. (103b)), just like Afrikaans - $e$ in ' $n$ swarte and Frisian -en in in swarten.
a. [een [NP Zwarte [NP ONE]]]
(elision strategy)
b. [een [NP zwart [NP $e]]]$ (pronominalization strategy)

We believe that there are a number of reasons for choosing the structural analysis in (103b). First of all, none of the dialects that make use of the elision strategy (e.g., Asten Dutch) add a (default) inflectional suffix to the adjectival remnant; i.e., the adjectival remnant typically remains morphologically bare (cf. (90c)). To put it differently, the inflection on the adjective is expected to be insensitive to NPE and hence it is expected that the same inflectional paradigm is found in non-ellipsis and ellipsis contexts. ${ }^{35}$ Secondly, the fact that some speakers accept the elided pattern een zwart next to een zwarte also suggests that the former pattern is the true 'ellipsis pattern' and the latter an instance of the pronoun strategy. This co-existence of two strategies has also been found for dialectal variants of Dutch, e.g., in Sliedrecht Dutch (spoken in the province of South-Holland/The Netherlands) and Nijkerk Dutch (spoken in the province of Gelderland/the Netherlands):

\footnotetext{
${ }^{35}$ One other analysis is that NPE involes a covert pro-form with either a default gender feature or without a gender feature. In both cases the default inflectional affix $-e$ is expected to occur on the adjective (see also discussion about Frisian and Zierikzee Dutch in Sect. 6.3 above). This affix could be argued to be the result of an agreement relation between the adjective and the covert pro-form with default gender features. A problem with this analysis will be discussed in fn. 40 below.
} 
(104) a. Ik heb een wit knijn en jij een zwart(e).

(Sliedrecht Dutch)

I have a white rabbit and you a black(-e)

'I have a white rabbit and you a black one.'

b. Ik het een wit knien en jie een $\operatorname{zwart}(e)$. I have a white rabbit and you a black $(-e)$

(Nijkerk Dutch)

Quite interestingly, in certain variants of Dutch, the two strategies can be formally distinguished from each other on the basis of DP-internal contextual effects. One such variant is Ossendrecht Dutch.

In Ossendrecht Dutch (spoken in the province of Northern Brabant/The Netherlands) we find the adjectival paradigm in (105) for indefinite singular noun phrases. This paradigm displays a three-way gender distinction in the adjectival form.

(105) a. ne leuken opa

(masculine gender indefinite)

a nice-en grandfather

b. een leuke oma (feminine gender indefinite)

a nice-e grandmother

c. een leuk kind (neuter gender indefinite)

a nice child

According to our consultants, two adjectival forms are possible in the ellipsis patterns in (106) and (107), a bare form A (zwart/groot) and a non-bare form $\mathrm{A}+e$ (zwarte/grote). What is interesting is that this difference in (adjectival) form correlates with a difference in the form of the indefinite article/indefinite demonstrative: ${ }^{36}$

(106) a. Ik heb een wit konijn, en jij [een zwart].

$($ konijn $=$ neuter $)$

I have a white rabbit and you a black

'I have a black rabbit and you a white one.'

b. Ik heb een wit konijn, en jij [ne zwarte].

I have a white rabbit and you a black-e

'I have a white rabbit and you a white one.'

(107) [talking about houses...]

(huis 'house' $=$ neuter)

a. [zo'n groot] ziede maar zelden!

such.a big see.you but rarely

'You hardly ever see such a big one (i.e., house)!'

\footnotetext{
${ }^{36}$ Other dialects from the DiDDD-project which display this phenomenon are: Groenlo Dutch (province of Gelderland/The Netherlands), Vorstenbosch Dutch (province of Northern Brabant/The Netherlands) and Maasbree Dutch (province of Limburg/The Netherlands). Consider, for example, the following pair from Maasbree Dutch:
}

(i) [Talking about sweet candies...] (zuurke 'candy' = neuter)
a. Ik wil zo'n groot geel
niet zo'n klein geel.
I want such.a big yellow not such.a small yellow
b. Ik wil zonne grote gele niet zonne kleine gele.
I want such.a big-e yellow-e not such.a small-e yellow-e
'I want such a big yellow one not such a small yellow one.' 
b. [sonne grote] ziede maar zelden!

such.a $a_{\text {masc }}$ big see.you but rarely

'You hardly ever see such a big one (i.e., house)!'

In (106a-107a), we find the indefinite article een and the related indefinite demonstrative form zo'n, which can combine with neuter nouns (cf. een leuk kind in (105c) and zo'n leuk kind, 'such a nice child'). In (106b-107b), on the contrary, we find the form of the indefinite article/demonstrative (ne/sonne), which is typically associated with masculine gender. We propose that the elided noun phrase in (106a-107a) instantiates the pattern in (103a), and that the one in (106b-107b) instantiates the pattern in (103b). Importantly, the pro-form $e$ in the b-examples is taken to be a genderless pro-form (just like the Frisian and Zierikzee Dutch pro-form en). We further assume that the masculine form of the indefinite article $n e$ in (106b) and the indefinite demonstrative sonne in (107b) are used as default forms.

Turning now to Standard Dutch, consider again the following facts:

Jan heeft [een wit konijn] en Marie heeft [een zwarte]/\%[een
Jan has a white rabbit ${ }_{[+ \text {neuter] }}$ and Marie has a black-e/a
zwart].
black
'Jan has a white rabbit and Marie has a black one.'

b. Jan heeft [een witte hond] en Marie heeft [een zwarte]. Jan has a white- $e \operatorname{dog}_{[- \text {neuter }]}$ and Marie has a black-e 'Jan has a white dog and Marie has a black one.'

We propose that Dutch essentially behaves like Frisian. Recall that the two languages display the same behavior with respect to the morphological inflection on the attributive adjective modifying an overt noun. For both languages it holds that the attributive adjective is always followed by a schwa (i.e., orthographically $-e$ ), except when the noun phrase is indefinite, neuter and singular. For Frisian, we argued that a surface form like in swarte (a black-e, 'a black one') has the following more abstract representation: [DP in [NP swart-e [NP IEN]]]. Importantly, however, this inflected form was impossible when ien was associated with a neuter singular antecedent noun. It was shown that Frisian in these cases exhibits the pronominalization strategy for NPE. More specifically, a weak (genderless) pro-form en functions as a pro-noun, as in in swarten (a black-en, 'a black one'). Importantly, this pronominal form could 'replace' both a non-neuter noun and a neuter noun.

We would like to propose now that in standard Dutch—but arguably also dialects such as Sliedrecht Dutch and Nijkerk Dutch; see (104)—we have the same two systems of NPE as in Frisian: i.e., (i) the elision strategy, where presence of agreement morphology on the adjective is crucial for the licensing of the silent noun ONE, and (ii) the pronominalization strategy, i.e., the presence of a phonologically weak proform. The difference between Frisian and Dutch is that in Frisian the inflection (-e) and the pro-form (-en) are distinguishable in pronunciation, whereas in Dutch they are not; the pro-form is $e$, and thus phonologically identical to (i.e., homophonous with) the adjectival inflection $-e$. The simultaneous similarity (i.e., as regards the 
available NPE-strategies) and difference (i.e., as regards the form of the pro-form) between Frisian and Dutch is depicted in the following table: ${ }^{37}$

\begin{tabular}{|l|l|l|l|l|}
\cline { 2 - 5 } \multicolumn{1}{c|}{} & \multicolumn{2}{c|}{ Elision strategy } & \multicolumn{2}{c|}{ Pronominalization strategy } \\
\cline { 2 - 5 } \multicolumn{1}{c|}{} & Indef. common sg. & Indef. neuter sg. & Indef. common sg. & Indef. neuter sg. \\
\hline Frisian & in swarte & \%in swart & in swarten & in swarten \\
\hline Dutch & een zwarte & \%een zwart & een zwarte & een zwarte \\
\hline $\begin{array}{l}\text { Underlying } \\
\text { Representation }\end{array}$ & $\begin{array}{l}\text { in swarte ONE } \\
\text { een zwarte ONE }\end{array}$ & $\begin{array}{l}\text { \%in swart-ø ONE } \\
\text { \%een zwart- } ø \text { ONE }\end{array}$ & $\begin{array}{l}\text { in swart } e n \\
\text { een zwart } e\end{array}$ & $\begin{array}{l}\text { in swart } e n \\
\text { een zwart } e\end{array}$ \\
\hline
\end{tabular}

As is clear from the 'Dutch' row, the elision strategy and the pronominalization strategy with common nouns results in the same surface representation. However, the underlying representation is quite different. On the basis of micro-comparative syntactic research (e.g., comparison with Frisian) the existence of two NPE-strategies can be motivated for standard Dutch. ${ }^{38}$

${ }^{37}$ Remember from our discussion of Frisian that we take its pro-form en to be gender-less. Thus, strictly speaking, the fourth and fifth column in (109) can be reduced to a single column. In what follows, we will argue that this absence of gender-specification also applies to the Dutch weak pro-form $e$. Thus, also for this language the two columns can be reduced to one. We have simply included two separate columns for expository purposes.

${ }^{38}$ A reviewer points out another potential test for identifying apparent adjectival inflections as weak pronouns. The test is based on the behavior of (Germanic) adjective phrases in which the degree word enough follows the adjective and consequently precedes the noun, as in the English examples a [big enough] rabbit and a [big enough] one. As noted in van Riemsdijk (1998) for Dutch, this adjectival pattern is only possible when the adjective does not carry an overt inflection, as in (i). When an adjectival inflection is required, as in (ii), we get an ill-formed pattern: the inflection can neither appear on the adjective (iib) nor on the degree-adverb (iic). Leaving out the inflection is not permitted either (iid).

(i) a. een groot konijn

(indef.neut.sg.)

[Dutch]

b. een groot genoeg konijn

a big enough rabbit

(ii) a. een grote hond

b. *een grote genoeg hond

a big- $e$ enough dog

c. *een groot genoege hond

a big enough-e dog

d. *een groot genoeg hond

a big enough dog

If in the NPE-counterpart of (ia), i.e., een grote (a big, 'a big one'), the final - $e$ is a pro-noun, then there might be a difference in acceptability, compared to the pattern in (iic), when the pro-noun - $e$ follows groot genoeg, as in (iii). As indicated, however, there does not seem to be any difference in acceptability between (iic), where $-e$ is an adjectival inflection, and (iii), where $-e$ is a weak pro-noun.

(iii) *een groot genoeg-e

[Dutch]

a big enough-e

'a big enough one (i.e., rabbit)'

As pointed out by the examples in (iv), this also holds for Afrikaans; recall that in Afrikaans it is possible to say: 'n groot een/ene (a big one) and 'n grote (a big-e, 'a big one'). 
From the perspective of our decompositional analysis of pro-nouns the structure of the two NP-patterns in Dutch can be more precisely represented as follows:
(110)
$\begin{array}{ll}\text { a. } & {\left[\mathrm{DP} \text { een }\left[\mathrm{nP} \text { zwart- } e /-\phi\left[\mathrm{nP}_{\mathrm{ONE}}[\mathrm{ONE}]_{\mathrm{j}}\left[\mathrm{n}^{\prime} \mathrm{n}^{\circ}(=\varnothing) \mathrm{t}_{\mathrm{j}}\right.\right.\right.\right.} \\ \text { b. } & {\left[\mathrm{DP} \text { een }\left[\mathrm{nP} \text { zwart }\left[\mathrm{nP}[\mathrm{ONE}]_{\mathrm{j}}\left[\mathrm{n}^{\prime} \mathrm{n}^{\circ}(=\mathrm{e}) \mathrm{t}_{\mathrm{j}}\right]\right]\right]\right]}\end{array}$
(pronominalization strategy)

Just as we did for the Frisian and Zierikzee Dutch NPE-patterns involving an adjectival remnant consisting of more than one adjective, we should make the following additional remark about standard Dutch. When the adjectival remnant consists of a sequence of adjectives, the leftmost adjective clearly carries an inflectional marker $-e$, as in:

(111) Jan heeft [een groot wit konijn]

en Marie heeft [een kleine zwarte] Jan has a big white rabbit ${ }_{[+ \text {neuter] }}$ and Marie has a small-e black- $e$ 'Jan has a big white rabbit and Marie has a small black one' (standard Dutch)

Recall from the Frisian example in (78b) (but the same holds for the Zierikzee Dutch example in (97b)) that certain speakers find the form in grutte swarten (a big-e blacken 'a big black one') quite acceptable. We proposed that the $e$ on grutte is a default inflection, which is inserted because the pro-noun en does not carry a gender feature. We further argued that this same default inflection showed up on the adjective adjacent to the pro-form en, but that it did not surface as result of haplology; i.e., the inflection - $e$ (schwa) is deleted since it precedes another schwa.

We will argue that this Frisian state of affairs also holds for Dutch. This implies that the NPE-pattern een kleine zwarte in (111) has the following representation, where (112a) represents the initial structural analysis and (112b) the decompositional one: ${ }^{39}$

(112) a. [een [NP kleine [NP zwarte [NP $\boldsymbol{e}]]]]$

$(=$ een kleine zwarte)

b. [een $\left[{ }_{n P}\right.$ kleine $\left[\mathrm{NP}\right.$ Zwart-e $\left.\left.\left.\left[\mathrm{nP}[\mathrm{ONE}]_{\mathrm{j}}\left[\mathrm{n}^{\prime} \mathrm{n}^{\circ}(=\mathrm{e}) \mathrm{t}_{\mathrm{j}}\right]\right]\right]\right]\right]$

We close off this section with the two NPE-examples from Standard Dutch that were discussed in (85) and (86) above and which can now be analyzed as instances of

\footnotetext{
(iv) a. ['n groot genoeg konyn]

b. ['n groot genoeg een/ene]

c. *['n groot genoeg-e]
}

[Afrikaans]

The data in (iii) and (iv) suggest that there is an independent restriction which blocks the phonological attachment of the weak pro-form $e$ to the adverb genoeg. In short, these structural patterns do not provide additional evidence for the pro-nominal status of $e$.

${ }^{39}$ Thus, in swarten and een zwarte in columns 4 and 5 in (109) are more precisely represented as in (i) under the 'simplex' analysis of pro-nouns and as in (ii) under the decompositional analysis of pro-nouns.

(i) a. [in [NP swarte [NP en]]]

b. [een [NP Zwarte [NP $e]]]$

[Frisian]

(ii) a. [DP in $\left[{ }_{n P}\right.$ swart-e $\left.\left.\left[{ }_{n P}[O N E]_{j}\left[n^{\prime} n^{\circ}(=e n) t_{j}\right]\right]\right]\right]$

[Dutch]

b. [DP een $\left[n P\right.$ zwart-e $\left.\left.\left[n P[O N E]_{j}\left[n^{\prime} n^{O}(=e) t_{j}\right]\right]\right]\right]$

[Frisian]

[Dutch] 
the pro-form strategy. The relevant examples are repeated here as (113) and (114), respectively:

(113) a. Ik heb gisteren [ een groot/grote pianist] horen spelen.

I have yesterday a big / big-e pianist hear play

'I have heard a great / big pianist yesterday.'

b. Ik heb gisteren [ een echt grote] horen spelen.

I have yesterday a real big-e hear play

'I have heard a truly big/great one yesterday.'

(114) a. het doorbakken(*e) konijn

the well-baked(-e) rabbit

'the well-baked rabbit'

b. het doorbakken*(e)

the well-baked(-e)

'the well-baked one'

Recall that the presence of the $e$-ending on the adjective groot 'big/great' in (113a) affects its meaning: when it is present, the adjective means 'big', whereas it means 'great' when it is absent. As shown in (113b), the adjective must carry an $e$-suffix independent of its meaning, when it occurs as an adjectival remnant in an ellipsis context. So, also in this case the $e$-suffix obligatorily shows up when the noun is elided. Consider next the examples in (114). Example (114a) shows that adjectives that are derived from past participles cannot show inflection in attributive contexts. However, as shown in (114b), these participial adjectives need to get the inflection when used in ellipsis contexts.

In view of the previous discussion, we propose that the $e$ in (113b) and (114b) is a weak pro-form that substitutes for the noun. The representations of the two NPEpatterns are given in (115), where we use the simplex analysis of pro-nouns:

(115) a. [DP een [NP echt grote [NP e]]]

b. [DP het [NP doorbakken [NP e]]]

As indicated in (115a), we will assume that groot 'big' gets a default inflection - $e$ (see the discussion in and around example (112) above). This inflection is subsequently eliminated, however, as a result of haplology.

In Sect. 3 on Afrikaans and in Sect. 5 on Frisian we have used a test in order to determine whether a certain ending appearing on adjectives in NPE-contexts is an adjectival inflection or not. In particular we have argued that the ending is not an adjectival inflection if it does not appear on all adjectives when the remnant of NPE contains more than one adjective (see example (100) from Frisian). For standard Dutch this test does not work so well, since in this language the pro-form is homophonous to the adjectival inflection. There is one context, however, where the adjectives do not (overtly) agree with the pro-form $e$, namely when the adjectives are derived from past participles ending in -en (see (114) above). This means that if the remnant of ellipsis consists of more than one adjective derived from a past participle ending with -en, we expect only the last one to carry an $e$-ending. This ending is not, as we argued above, an adjectival inflection but a weak pro-form. This prediction is borne out by the data in (116-117). 
(116) a. het gezouten $(* e)$ visje

the salted-e fish ${ }_{\text {dim }}$

'the salted fish'

b. het gebakken $\left({ }^{*} e\right)$ visje

he fried-e fish ${ }_{\text {dim }}$

'the fried fish'

c. het gezouten gebakken visje

the salted fried fish $_{\text {dim }}$

'the salted fried fish'

(117) a. het gezouten gebakken*(e)

the salted fried-e

'the salted fried fish'

b. het gezouten $(* e)$ gebakken* $(e)$

the salted-e fried-e

The data in (116) show that the adjectival inflection $-e$ is not permitted after the participle in a complete (i.e., non-elliptical) noun phrase. The examples in (117) indicate that in an elliptical noun phrase, only the final participle of the remnant can be followed by the bound morpheme $e$. This suggests again that this $e$ is not an adjectival inflection, but rather a pro-form. Notice also that these data once again confirm that the Dutch $-e$ is homophonous between an adjectival inflection and a weak proform. ${ }^{40}$

In summary: by taking a micro-comparative perspective on NPE in Dutch, we have identified two NPE-strategies in Standard Dutch, viz. the elision strategy and the pronominalization strategy. An important aid in our analysis of Dutch NPE was Frisian. The latter language formally distinguishes the pro-form and the adjectival inflection, viz. en versus - $e$. In Dutch, the pro-form and the inflectional marker are homophonous, i.e., $-e$. As a consequence of that, the pro-form strategy is difficult to identify. We further showed that there are Dutch dialects which make use of a single strategy: the elision/agreement strategy (Asten Dutch) or the pronominalization strategy (Zierikzee Dutch).

\section{Conclusion}

In this article we investigated the syntax of NP-ellipsis. Traditionally, two strategies of NP-ellipsis are distinguished: (a) the elision strategy, and (b) the pronominalization strategy. The former has been said to be dependent on the presence of inflectional morphology (i.e., agreement) on the adjectival remnant. The latter strategy is used when the adjectival remnant does not carry any inflectional morphology. The major aim of this article was to show that there are languages in which morphological agreement appears to be the licensing factor, but where the pronominalization

\footnotetext{
${ }^{40}$ These data also provide an argument against the analysis put forward in fn. 36 that the $e$-ending on adjectives in NPE-cases of a neuter singular indefinite noun are actually agreement affixes resulting from the agreement relation between the adjective and a covert pro-form with default gender features or without gender features. If the $e$-ending were an agreement affix, we would expect it to appear on both adjectives.
} 
strategy is the actual strategy. We arrived at this conclusion via an in-depth and systematic micro-comparative investigation of the NP-ellipsis phenomenon in a number of closely related languages and dialects, more specifically: Afrikaans, Frisian, (standard) Dutch and dialectal variants of Dutch. An important empirical outcome of our investigation was that for a better understanding of the nature of NPE, it is crucial to include instances of NPE involving complex adjectival remnants, i.e., adjectival remnants containing more than one adjective. On the basis of such NPE-patterns, it was shown that the $e$ in Afrikaans ' $n$ swarte and Dutch ' $n$ zwarte and the $e n$ in Frisian in swarten and Zierikzee Dutch een zwarten are weak pro-nouns. We further showed that some languages make use of a single strategy (e.g., Afrikaans only uses the pronominalization strategy and Asten Dutch only uses the elision strategy), while others use both (e.g., Frisian and Standard Dutch). The co-existence of two NPEstrategies in a single language shows that the choice of strategy is not simply a matter of parameterization defined by UG (i.e., language L uses (a) pronominalization or (b) elision for the expression of NP-ellipsis). In line with current assumptions about the nature of parameterization, it was argued that inter- and intra-linguistic variation results from properties associated with the functional categories of human language. More specifically, adopting a decompositional analysis of pro-nouns, we argued that, across languages, pro-nouns consist of a category-defining functional head $\mathrm{n}^{\circ}$ and a root. The formal manifestation of this pro-nominal 'schema' depends on a number of factors which are associated with the functional head n, such as: (a) the lexicalization of $\mathrm{n}^{\circ}$ (i.e., zero-realization or phonological realization as $e$ ); (b) the nature of the movement operation applied to the root, which is triggered by the functional head $n^{\circ}$ (i.e., head movement to $n^{\circ}$ or movement to SpecnP); (c) the spell-out of the pronominal structure at PF (e.g., pronunciation as one/een/ien or non-pronunciation as a silent element, the latter being restricted to the syntactic position SpecnP). It was shown that this decompositional analysis of the pro-noun leads to a unified analysis of the pronominalization strategy and the elision strategy.

We close off this section by giving a summarizing overview of the various NPEpatterns discussed in this article. The left column represents the derived NP-ellipsis structure. The middle column gives some instantiations of the NPE-pattern as attested across the languages/dialects examined in this article. The third column presents the n-related grammatical properties (the microparameters) that define the inter- and intra-linguistic variation.

\begin{tabular}{|c|c|c|}
\hline Pattern of NP-ellipsis & Languages/Dialects & Properties \\
\hline$\left[\mathrm{DP}\right.$ in $\left[\mathrm{nP}_{\mathrm{P}}\right.$ swarte $\left[\mathrm{nP}\left[\mathrm{n} \mathrm{n}^{\circ}(=\mathrm{en})\right]\right.$ ien $\left.\left.]\right]\right]$ & in swarten ien (Fris.) & $\begin{array}{l}-\mathrm{n}=e n \\
\text { - ien is in situ }\end{array}$ \\
\hline$\left[\mathrm{DP}\right.$ a $\left[\mathrm{nP}\right.$ black $\left.\left.\left[\mathrm{nP}\left[\mathrm{n}[\text { one }]_{\mathrm{j}} \mathrm{n}^{\circ}\right] \mathrm{t}_{\mathrm{j}}\right]\right]\right]$ & $\begin{array}{l}\text { a black one (Eng.) } \\
\text { 'n swart een (Afr.) }\end{array}$ & $\begin{array}{l}\cdot \mathrm{n}=\varnothing \\
\cdot \sqrt{ } \text {-to-n movement }\end{array}$ \\
\hline$\left[\mathrm{DP}\right.$ 'n [nP swart $\left.\left.\left[\mathrm{nP}_{\mathrm{nP}}\left[\mathrm{n}[\text { een }]_{\mathrm{j}} \mathrm{n}^{\mathrm{o}}(=\mathrm{e})\right] \mathrm{t}_{\mathrm{j}}\right]\right]\right]$ & 'n swart ene (Afr.) & $\begin{array}{l}-\mathrm{n}=e \\
-\sqrt{ } \text {-to-n movement }\end{array}$ \\
\hline$\left[\mathrm{DP}{ }^{\prime} \mathrm{n}\left[\mathrm{nP}\right.\right.$ swarte $\left.\left.\left[{ }_{\mathrm{nP}}[\mathrm{EEN}]_{\mathrm{j}}\left[\mathrm{n}^{\prime}\left[\mathrm{n}^{\circ}(=\mathrm{e})\right] \mathrm{t}_{\mathrm{j}}\right]\right]\right]\right]$ & $\begin{array}{l}\text { 'n swarte (Afr.) } \\
\text { in swarten (Fris.) } \\
\text { een zwarten (Zierikzee Du.) } \\
\text { een zwarte (St. Du.) }\end{array}$ & $\begin{array}{l}\text { - } \mathrm{n}=\text { e/en } \\
\text { - XP-movement of } \sqrt{ } \text { to SpecnP } \\
\text { - } \sqrt{\text { in SpecnP is unpronounced }} \\
(\mathrm{ONE})\end{array}$ \\
\hline$\left[\mathrm{DP}\right.$ een $\left[\mathrm{nP}\right.$ ZWarte $\left.\left._{[\mathrm{agr}]}\left[\mathrm{nP}[\mathrm{EEN}]_{\mathrm{j}}\left[\mathrm{n}^{\circ}\left[\mathrm{n}^{\circ}(=\varnothing)\right] \mathrm{t}_{\mathrm{j}}\right]\right]\right]\right]$ & 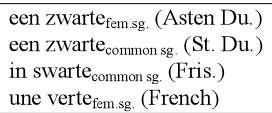 & $\begin{array}{l}-\mathrm{n}=\varnothing \\
-\mathrm{XP}-\text { movement of } \sqrt{ } \text { to SpecnP } \\
\text { - } \sqrt{\text { in specnP is umpronounced }} \\
(\mathrm{ONE})\end{array}$ \\
\hline
\end{tabular}


The second through fourth row included represent the pronominalization strategy, the fifth row the elision strategy. In the latter configuration both the n-head and the root remain unpronounced. In such a representation, the categorical contents of the 'silence' can be recovered on the basis of the agreement properties associated with the adjectival remnant. In the other NPE-structures, the categorical nature surfaces via lexicalization of $n^{\circ}$ or movement of the root to $n^{\circ}$.

In this article, we have come to a typology of NPE-patterns on the basis of an in depth microvariation analysis of closely related languages and dialects. Given the fact that the micro-parameters in (118) are associated with the functional system of human language (more specifically the functional category $n$ ), we expect similar patterns to be found in typologically less closely related languages as well. This is certainly an issue for future research.

Open Access This article is distributed under the terms of the Creative Commons Attribution Noncommercial License which permits any noncommercial use, distribution, and reproduction in any medium, provided the original author(s) and source are credited.

\section{References}

Abney, Steven. 1987. The English noun phrase in its sentential aspect. Doctoral dissertation, MIT, Cambridge.

Alexiadou, Artemis, and Elena Anagnostopoulou. 1998. Parametrizing AGR: Word order, V-movement and EPP-checking. Natural Language \& Linguistic Theory 16: 491-539.

Baker, Carl L. 1978. Introduction to generative-transformational syntax. Englewood Cliffs: Prentice-Hall.

Baltin, Mark, and Jeroen van Craenenbroeck. 2008. On becoming a pronoun, towards a unified theory of ellipsis. Handout presented at The 10th CUNY/SUNY/NYU/ $+Y$ miniconference at CUNY, New York.

Barbiers, Sjef. 2005. Variation in the morphosyntax of ONE. The Journal of Comparative Germanic Linguistics 8: 159-183.

Borer, Hagit. 1984. Parametric syntax. Dordrecht: Foris.

Borer, Hagit. 2005. Structuring sense. Volume I: In name only. Oxford: Oxford University Press.

Broekhuis, Hans, Evelien Keizer, and Marcel den Dikken. 2003. Nouns and noun phrases. Modern grammar of Dutch. Occasional papers 4. Tilburg.

Cardinaletti, Anna. 1998. On the deficient/strong opposition in possessive systems. In Possessors, predicates and movement in the determiner phrase, eds. Artemis Alexiadou and Chris Wilder, 17-53. Berlin: Mouton de Gruyter.

Cardinaletti, Anna, and Michal Starke. 1999. The typology of structural deficiency: a case study of the three classes of pronouns. In Clitics in the languages of Europe, ed. Henk van Riemsdijk, 145-233. Berlin: Mouton de Gruyter.

Chomsky, Noam. 1995. The minimalist program. Cambridge: MIT Press.

Chomsky, Noam. 2001. Derivation by phase. In Ken Hale. A life in language, ed. Michael Kenstowicz, 1-52. Cambridge: MIT Press.

Corver, Norbert, and Denis Delfitto. 1999. On the nature of pronoun movement. In Clitics in the languages of Europe, ed. Henk van Riemsdijk, 799-861. Berlin: Mouton de Gruyter.

Corver, Norbert, and Marjo van Koppen. 2009. Let's focus on noun phrase ellipsis. Groninger Arbeiten zur Germanistischen Linguistiek (GAGL) 48: 3-26.

Corver, Norbert, and Marjo van Koppen. 2010. Ellipsis in Dutch possessive noun phrases: A microcomparative approach. The Journal of Comparative Germanic Linguistics 13: 99-140.

Corver, Norbert, Marjo van Koppen, Huib Kranendonk, and Mirjam Rigterink. 2007. The noun phrase: diversity in Dutch DP design. Nordlyd 34: 73-85.

de Belder, Marijke. 2008. Size Matters: Towards a syntactic decomposition of countability. In Proceedings of the 27th west coast conference on formal linguistics, eds. Natasha Abner, Jason Bishop, and Kevin Ryan. Somerville: Cascadilla Proceedings Project. 
Déchaine, Rose-Marie, and Martina Wiltschko. 2002. Decomposing pronouns. Linguistic Inquiry 33: 409442 .

Donaldson, Bruce. 1993. A grammar of Afrikaans. Berlin: Mouton de Gruyter.

Embick, David, and Alec Marantz. 2008. Architecture and blocking. Linguistic Inquiry 39: 1-53.

Emonds, Joseph. 1985. A unified theory of syntactic categories. Dordrecht: Foris.

Hoekema, Teake. 1996. Beknopte Friese Vormleer. Leeuwarden/Ljouwert: Afûk.

Holmberg, Anders. 1991. The distribution of Scandinavian weak pronouns. In Clitics and their Hosts, eds. Henk van Riemsdijk and Luigi Rizzi, 155-174. Tilburg: ESF Eurotype.

Jackendoff, Ray. 1977. X-bar syntax: a study of phrase structure. Cambridge: MIT Press.

Kayne, Richard. 2003. Silent years, silent hours. In Grammar in focus. Festschrift for Christer Platzack, eds. Lars-Olof Delsing, Gunlög Josefsson, Halldór Sigurdsson, and Cecilia Falk, 209-226. Lund: Wallin and Dalholm.

Kayne, Richard. 2005. On the syntax of quantity in English. In Movement and silence. New York: Oxford University Press.

Kester, Ellen-Petra. 1996. The nature of adjectival inflection. Doctoral dissertation. Utrecht University.

Lakoff, George. 1970. Global rules. Language 46: 627-639.

Lobeck, Anne. 1991. The phrase structure of ellipsis. In Perspectives on phrase structure: Heads and licensing, ed. Susan Rothstein, 81-103. San Diego: Academic Press.

Lobeck, Anne. 1995. Ellipsis: Functional heads, licensing and ellipsis. New York: Oxford University Press.

Marantz, Alec. 1997. No escape from syntax: don't try morphological analysis in the privacy of your own lexicon. In Proceedings of the 21st Penn linguistics colloquium, eds. Alexis Dimitriadis, Laura Siegel, Clarissa Surek-Clark, and Alexander Williams, 201-225. UPenn Working Papers in Linguistics, Philadelphia.

Muysken, Pieter, and Henk van Riemsdijk. 1986. Projecting features and featuring projections. In Features and projections, eds. Pieter Muysken and Henk van Riemsdijk, 1-30. Dordrecht: Foris.

Panagiotidis, Phoevos. 2003a. Empty nouns. Natural Language \& Linguistic Theory 21: 381-432.

Panagiotidis, Phoevos. 2003b. One, Empty Nouns and Theta Assignment. Linguistic Inquiry 34: 281-292.

Perlmutter, David. 1970. On the article in English. In Progress in linguistics: a collection of papers, eds. Manfred Bierwisch, and Karl E. Heidolph, 233-248. The Hague: Mouton.

Peters, P. 1938. Het zelfstandig gebruikte adjectief en het geslacht. Onze Taaltuin VII: 22-25. http://www.dbnl.org/tekst/_taa011193801_01/_taa011193801_01.pdf

Postal, Paul. 1969. On so-called pronouns in English. In Modern studies in English, eds. David Reibel and Sanford Schane, 201-223. Englewood Cliffs: Prentice-Hall.

Roeper, Tom. 2007. The prism of grammar. How child language illuminates humanism. Cambridge: MIT Press.

Rooryck, Johan. 1994. On 0- and $\alpha$-underspecification in syntax and phonology. In The morphology-syntax connection, eds. Heidi Harley and Colin Phillips, Vol. 22 of MIT working papers in linguistics, 197216. Cambridge: MIT Press.

Ross, John R. 1967. Constraints on variables in syntax. Doctoral Dissertation MIT.

Schütze, Carson. 2001. Semantically empty lexical heads as last resorts. In Semi-lexical categories, eds. Norbert Corver and Henk van Riemsdijk, 127-187. Berlin: Mouton de Gruyter.

Uriagereka, Juan. 1995. Aspects of the syntax of clitic placement in Western Romance. Linguistic Inquiry 26: 79-123.

van Riemsdijk, Henk. 1998. Head movement and adjacency. Natural Language \& Linguistic Theory 16: 633-678.

Wiltschko, Martina. 1998. On the internal and external syntax and semantics of (relative) pronouns. Journal of Comparative Germanic Linguistics 2: 143-181.

Wiltschko, Martina. 2005. Why should diminutives count. In Organizing grammar. Linguistic studies in honor of Henk van Riemsdijk, eds. Hans Broekhuis, Norbert Corver, Riny Huybregts, Ursula Kleinhenz, and Jan Koster, 669-679. Berlin: Mouton de Gruyter. 